\title{
Towards better performances for a novel rooftop solar PV system
}

\author{
Arun Kumar Behura ${ }^{1}$, Ashwini Kumar², Dipen Kumar Rajak ${ }^{3 *}$, \\ Catalin I. Pruncu ${ }^{4}, 5^{*}$, Luciano Lamberti ${ }^{6}$
}

${ }^{1}$ School of Mechanical Engineering, Vellore Institute of Technology, Vellore, India

${ }^{2}$ Department Mechanical Engineering, National Institute of Technology, Jharkhand, India

${ }^{3}$ Department of Mechanical Engineering, Sandip Institute of Technology and Research Centre, MH, India

${ }^{4}$ Department of Mechanical Engineering, Imperial College London, Exhibition Rd., London, UK

${ }^{5}$ Design, Manufacturing \& Engineering Management, University of Strathclyde, Glasgow, G1 1XJ, UK

${ }^{6}$ Dipartimento di Meccanica, Matematica e Management, Politecnico di Bari, Bari, Italy

*Corresponding author email: catalin.pruncu@strath.ac.uk ; dipen.pukar@gmail.com

\begin{abstract}
Solar photovoltaic (PV) systems are used worldwide for clean production of electricity. Photovoltaic simulation tool serve to predict the amount of energy generated by the PV solar array structure. This paper presents the photovoltaic system installed on the rooftop of the G.D. Naidu Block at Vellore Institute of Technology (Vellore, India). A novel PV plant design is developed here in order to improve the energetic efficiency of an existing PV system. The effectiveness of proposed design is evaluated over an entire year using the PVsyst v6.70 software, which works on accurate plant specifications. For this purpose, Metronome 7.1 weather data sets of ambient temperature and radiation from PVsyst database are used for the investigation. The cost of the proposed PV system and the required payback period are analyzed as well. Simulation results demonstrate the superiority of the proposed PV system design over the existing one in terms of the amount of electric energy injected in the grid, energy conversion efficiency, and reductions in $\mathrm{CO}_{2} / \mathrm{SO}_{2} / \mathrm{NO}$ emissions. Performance ratio of proposed design (Design 2) is 0.791 whereas the existing design (Design 1) is only 0.704 . Design 2 provides $40 \mathrm{MWh}$ more energy to grid than Design 1 due to reducing shading losses. The daily system energy generated for Design 2 is maximum (in particular, 26-29\% higher than for Design 1) between March and May, when the sun is brightest and directly above our head. Shading analysis carried out for both designs revealed that the existing Design 1 has more shading loss while the proposed Design 2 may reduce this loss by about 11-13\%, which results in a better efficiency of energy production. The article also documents significant emission reduction and cost analysis calculation for the proposed Design 2.
\end{abstract}

Keywords: Energy-efficient systems, Solar PV arrays, Grid connected solar PV systems, Shadow analysis, 
32 Simulation tools

33

34

35

36

37

38 GW: Gigawatt

39 MW: Megawatt

40 SKY: Surya Shakti KisanYojana

41 KWp: Kilowatts Peak

42 LMDI: Logarithmic Mean Divisia Index

$43 \quad$ N-S: North-South direction

$44 \quad 2 \mathrm{D}: \quad 2$-dimensional

45 3D: 3-dimensional

$46 \quad \mathrm{X}$ : Shading Distance

47 Y: Height of the tilted PV panel

$48 \quad \gamma: \quad$ Azimuth angle

$49 \varnothing: \quad$ Solar altitude

50 ROI: Return of Investment

51 KWh: Kilowatt-hour

52 MWh: Megawatt-hour

53 IAM: Incidence angle Modifier

54 STC: Standard Test Condition

55 MPP: Maximum Power Point

56 PR: Performance Ratio

\section{Introduction}

59 Solar energy is one of the most readily available energy sources and may be converted into electric power in a

60 very clean manner using photovoltaic systems. Environmental issues related to global warming and greenhouse

61 emissions push more and more the engineering community towards searching for more renewable sources or

62 developing new technologies that may exploit clean energy sources. In the last decade, the renewable energy

63 sector has developed by a great extent in Northern countries like Sweden and Norway that became nearly $100 \%$ 
dependent for electricity on renewable sources. Few countries like Sweden and Norway have the ambition of achieving $100 \%$ energy production from renewable sources in the next 5-10 years. A tropical country like India has on average 300 sunny days per year and the capacity to produce more than 500,000 TWh/year (Goel, 2016). Kar et al. (2016) looked into the advancement of sun powered vitality probability and abuse in the Indian market additionally doing a financial evaluation. It was discovered that only $7 \%$ of PV settlements in India represent housetop sun powered undertakings. Since India is the third biggest contaminator of ozone depleting substances on the planet and intended to reduce discharges by $1 / 3$ by 2030 , advancing the utilization of clean sustainable power sources is significant. India means to cover $40 \%$ of its complete vitality request utilizing ecoaccommodating sources by 2030. In particular, it is intended to have $175 \mathrm{GW}$ clean sustainable power source limit, of which $100 \mathrm{GW}$ of sunlight based vitality, $60 \mathrm{GW}$ of wind vitality, $10 \mathrm{GW}$ of bio-power (Biomass force and Waste to control age) and $5 \mathrm{GW}$ of Small hydro-power. Of the 100GW sun based vitality, $40 \mathrm{GW}$ will be for housetop sun oriented PV frameworks (private, business or modern) (Jain et al., 2018). In any case, India is a long way far from having the arranged limit of housetop close planetary system introduced and numerous challenges remain so as to accomplish the necessary limit. Abreu et al. (2019) analyzed problems and challenges faced by the PV market in India. Big investments are required in order to implement large scale renewable energy programs in growing countries like India (Shukla et al., 2018; Thakur et al., 2018). Innovative technologies and processes should be conceived in order to seize low radiation energy and optimize its transformation into actual power. The optimum power output must be estimated before the installation of the photovoltaic implant. Shading and resistive losses analyses play a crucial role before installation because they allow to predict and analyze the performance of the designed PV system. As is clear, disposing of accurate information on the actual behavior of the designed PV system will allow understanding how to optimize its efficiency, thus contributing to reduce the amount of energy generated from non-renewable sources and the emissions. Developing new, efficient and cheap storage solutions is the main challenge in PV systems design and technology. Research efforts focus on new materials and systems able to enhance energetic efficiency of PV panels, which is currently limited to about $15-25 \%$ all over the world (see, for example, https://news.energysage.com/what-are-the-most-efficient-solar-panels-on-themarket/).

Increasing efficiency and improving energy output of the PV panels has now become a global issue especially for growing countries such as, for example, India where, there are a few quality R\&D centers and not many PV system manufacturing companies. The Indian government regulated the use of solar PV systems within three types of business models (namely CAPEX model, OPEX/RESCO model, Utility owned/Lease Model) to 
guarantee good technological standards at a sustainable financial cost. The CAPEX Model became the most popular model while the other two models were not used (Overholm, 2015).However, none of the aforementioned models worked as expected in the Indian market and new business strategies were released to promote the use of rooftop solar PV systems. For example, the SKY (Surya Shakti KisanYojana) project was directed to farmers, giving more incentives for people to buy rooftop solar PV systems.

Another significant issue in structure and innovation of PV frameworks carefully identified with the advancement of more proficient vitality transformation and capacity advances is to limit the heaviness of photovoltaic boards. A PV board typically weighs $20-40 \mathrm{~kg}$. Since a PV framework clearly incorporates numerous boards, the all-out weight of the introduced plant is much bigger. Old/noteworthy structures whose vigorous proficiency ought to be expanded by PV establishments would probably not withstand heaviness of the PV framework beyond a certain limit. Reducing the basic load of the PV framework will solve this issue, make PV modules lighter and diminish transportation costs besides decreasing the cost of the materials used for the photovoltaic structure. Optimization studies on PV panels and systems have been carried out, for example, by Khare and Rangnekar (2013), Khatib et al. (2013), Cho et al. (2016), Singh et al. (2016), Alsadi and Khatib (2018), Zinaddinov et al. (2019), Ridha et al. (2020). Integration of PV systems with grids has been very recently optimized by Bawazir and Cetin (2020), Mohamed et al. (2020), Barakat et al. (2020), Mazzeo et al. (2020), Ashtiani et al. (2020). Structural integrity of PV panels also should be carefully considered in the design process. In fact, it is common to see snail trails localized at cell edge sand micro-fractures propagating across solar cells of PV modules. These defects may degrade performance of the PV system over time. Fatemeh et al. (2019) studied the application of solar energy technologies with energy life cycle assessment. Mobtaker et al. (2020) developed the system for utilization of energy, environment and exergy demand of irrigation system through application of photovoltaic system. Modules deteriorate faster than expected, thus reducing their life span (Meyer et al., 2013). Failure modes of photovoltaic systems and their impact on PV system performance were discussed, Cristaldi et al. (2014), Kim et al. (2016), Lillo-Bravo et al. (2018), Hocine and Samira (2019), Kumar et al. (2020), Nehme et al. (2017), Gallardo-Saavedra et al. (2019).

Simulation tools may turn very useful in optimizing the design process of photovoltaic systems. For example, the PVsyst software can analyze the potential of a photovoltaic system (Irwan et al., 2015) and predict how the installed system will perform in a near future. PVsyst simulations require input parameters such as the service conditions of PV panels, type and number of adopted inverters, sizing, available exposed area etc. (Yadav and Bajpai, 2018). PVsyst can also perform shadow analysis, tracking the sun path and analyzing how much 
shadow falls on the system. Data gathered from simulations can be used to analyze the performance of the PV system as well as to perform economic/cost analysis. For example, Allouhi et al. (2019) presented an environmental, extensive energy and economic analysis of $2.04 \mathrm{kWp}$ of polycrystalline (p-Si), $2.04 \mathrm{kWp}$ of monocrystalline $(\mathrm{m}-\mathrm{Si})$ and $1.86 \mathrm{kWp}$ of amorphous on microcrystalline (a-Si/ $\mu \mathrm{c}-\mathrm{Si})$ uniform silicon photovoltaic structures installed on the rooftop of twenty institutional buildings, situated in different Moroccan sites under various climatic conditions.

Modelling and simulation of PV systems are extensively documented in technical literature. The first important research area regards installation and utilization of PV systems in different regions of the world. Wang and Singh (2007) designed a grid connected hybrid energy system with multiple renewable sources of energy using a multi-objective particle swarm optimization (MOPSO) algorithm. Wang et al. (2012) analyzed the planning of a grid connected hybrid power system by means of Game Theory and multi-objective optimization. Wang and Yang (2013) developed an optimal capacity allocation of standalone wind/solar/battery hybrid power system using an improved particle swarm optimization algorithm. Hasan and Momin (2015) studied the performance analysis and feasibility of solar-wind-diesel hybrid energy system in rural areas of Bangladesh. Arefin and Das (2017) optimized a hybrid wind-diesel energy system accompanied by feasibility analysis with the use of HOMER software utilizing real time data of solar radiation, wind speed and biomass. Arefin et al. (2017) performed a feasibility analysis of renewable hybrid power generation plant in Manpura Island using HOMER software. Shezan et al. (2017) analyzed the techno-economic of a smart-grid hybrid renewable energy system settled in Brisbane (Australia) using the HOMER software with meteorological data. Good et al. (2014) analyzed the possibility of using solar energy in the urban areas of Norway. Economic assessment and issuance of photovoltaic modules and wind turbine in urban areas were analyzed by Mohammadi et al. (2014) while Jiang et al. (2018) carried out a feasibility study on the use of solar energy in Chinese rural villages. Rehman et al. (2018) analyzed the challenges entailed by locating a solar energy district at high latitudes; for that purpose, dynamic simulations were performed, and a multi-objective optimization algorithm was implemented also accounting for possible failures in planning. An LMDI (Logarithmic Mean Divisia Index) investigation was carried out by Chen et al., (2019) to explain the differences in the production of electricity through solar PV panels between China and USA. Farias-Rocha et al. (2019) performed an economic analysis of on-grid residential installations in the Philippines also focusing on existing regulations. Mohsenipour et al., (2020) analyzed the possibility of using solar-based trigeneration systems that can produce nearly zero-greenhouse energy in arid regions. The functional execution of MW-scale grids with rooftop solar photovoltaic structures in tropical wet and 
dry climate of India was investigated by Thotakura et al. (2020).

The second important area in the simulation of PV systems regards the prediction of power output of PV installations and the resulting interactions with the connected grid. For example, Sivaneasan et al. (2017) developed an improved solar forecasting algorithm based on artificial neural networks with fuzzy logic preprocessing; the proposed algorithm included correction factors to minimize predictions error on PV output power. The viability of small scale solar PV systems with grid connection was analyzed by Mandal and Panja (2016). Hossain et al. (2017) developed a new model for evaluating the power output of grid-connected PV systems; the model, based on extreme learning machine, was trained and tested using power output data and other meteorological parameters recorded in three grid-connected PV system. Krauter (2018) developed methods for matching the power output of a PV module with the profile of grid load in the simplest and most effective way. Robles-Campos et al. (2019) developed a simulation model for maximizing the available power from large-scale PV installations under conditions of partial shading. A gridded optimization model for studying applications of photovoltaic systems in Nordic countries was developed by Campana et al. (2020) using spatial and temporal data generated by mesoscale models. Mishra and Lal (2020) developed an enhanced mathematical model to control the reactive power of solar photovoltaic systems connected to grids; the analysis regarded the condition of maximum power. Heusinger et al. (2020) developed a new energy balance model that accurately simulates the complete diurnal dynamics of photovoltaic (PV) thermal behavior; the model was then related to PV conversion efficiency.

The last area of simulation methods covers the development of new design concepts and the optimization of PV installations. A recent review of solar energy applied patents was presented by Paulo and Porto (2018).Yu et al. (2019) reviewed 33 projects in the context of the Zero Energy Solar House framework; 7 key decisions and 24 strategies were identified and projects were ranked via multi-criteria analysis. Perea-Moreno et al. (2017) used a hierarchical temporal memory algorithm for detecting geometric patterns from aerial or space images; this served to identify the most suitable building roofs for installing solar thermal systems in small urban areas. Similarly, Li and Liu (2018) integrated a 3D pixel method with the Net Present Value (NPV) analysis to estimate solar energy potential over building surfaces; this was done in order to optimize PV installation strategies with desirable revenues over project lifetimes. Elbar et al., (2019) integrated a PV panel into a solar still and evaluated this new design concept on the basis of exergy, enviro-economic, energy and exergo-economic considerations. Kabeel and Abdelgaied (2019) developed a model to evaluate the performance of a new system integrating a PV module with reflectors, a cooling system into a solar still accompanied by air injection; the new design concept allowed to deal 
with scarcity of water and electricity in remote areas. Katekar and Deshmukh (2020) reviewed various solar still configurations in order to develop better designs with higher performance in practical applications; the use of photovoltaic panels increased efficiency by a considerable extent. Andler et al. (2020) developed a model for assessing the life cycle of a novel type of solar absorber; their ultimate goal was to understand the environmental impact of the proposed technology. Zheng et al. (2020) developed a new design methodology for movable green window shading systems.

The literature survey presented above reveals that a significant number of studies regarded standalone systems with no grid-connection. The most used software tools for those simulations were MATLAB Simulink, Solar GIS, PV Planner, HOMER, Solar Pro and RET Screen. The PVsyst software was usually employed to analyze big solar plants (with MW capacities) installed over very large areas. In the present study, the PVsyst v6.70 commercial software is used for simulating a small scale rooftop solar PV system of $248 \mathrm{~kW}$ capacities, also accounting for shading analysis; the software helped us to rank design solutions thus leading to develop a more efficient PV system. The research gap is that no published study focused on shadow analysis with performance ratio and cost analysis calculation using the PVsyst simulation software. The strength of a novel PV framework depends on daylight, has no moving parts, is secluded to coordinate force prerequisites on any scale, may have a long life and can be utilized autonomously or related to other electrical force source. Therefore, the present research is worked out to re-design the novel photovoltaic framework, which is introduced on the housetop of the G.D. Naidu Block in the Vellore Institute of Technology (Vellore, India). The existing PV plant will be denoted as Design 1 in the rest of the article. The available data for the existing system are utilized to design a novel PV system (indicated as Design 2 in the rest of the article), which can maximize energetic efficiency. The proposed Design 2 is then evaluated by carrying out numerical simulations that accurately reproduce the specifications of the PV plant. Simulations cover one entire year including the Meteonorm 7.1 weather data sets for real time solar radiation and ambient temperature. efficiency with enhanced performance ratio by using PVsyst software simulation on real time data gathered for the existing plant. The goal is to obtain a more efficiently designed PV plant than the existing one in terms of

210 performance ratio, daily energy efficiency, shadow analysis, cost analysis and emission analysis using PVsyst 211 software based on real time data on outdoor operating conditions. This work will provide PV panel industry with 212 useful guidelines on how to (i) optimize new installations; (ii) achieve higher efficiency in energy production and emissions reduction; (iii) develop new designs able to avoid shadows in specific areas. Users adopting the PV 
214 plant for domestic purpose or societal installation will make profit of this new technology for getting more

215 efficiency in the energy generation process and avoid shadow in their plant.

216 The rest of the article is structured as follows. The design methodology is outlined in Section 2, which

217 describes also the main components of the PV system and the rationale of PVsyst simulations. Section 3 describes

218 in detail the proposed PV system comparing it with the existing one. Section 4 compares the performance of the

219 proposed and existing PV systems. Finally, Section 5 summarizes the main findings of this study and outlines

220 directions for future research.

\section{Design methodology}

Figure 1 shows the schematic of a hybrid solar PV system. The main steps entailed by the design process of the new PV system developed in this research are now described in detail. The design framework follows the general principles discussed in Shukla et al. (2016). For PVsyst software simulation of this work, there are required the following real time data to analyze better design. Analysis of electric bills serves to determine the power consumption demand, which must be covered by the solar PV system. The average cost over the last 12 months is taken as reference value for sizing calculations and economic analysis. The main factors driving the selection of solar panels are cell type, system cost, warranty, panel size and installed power in Watts. Inverters are selected based on three factors: inverter-output AC power, DC-AC transformation efficiency and capital cost.

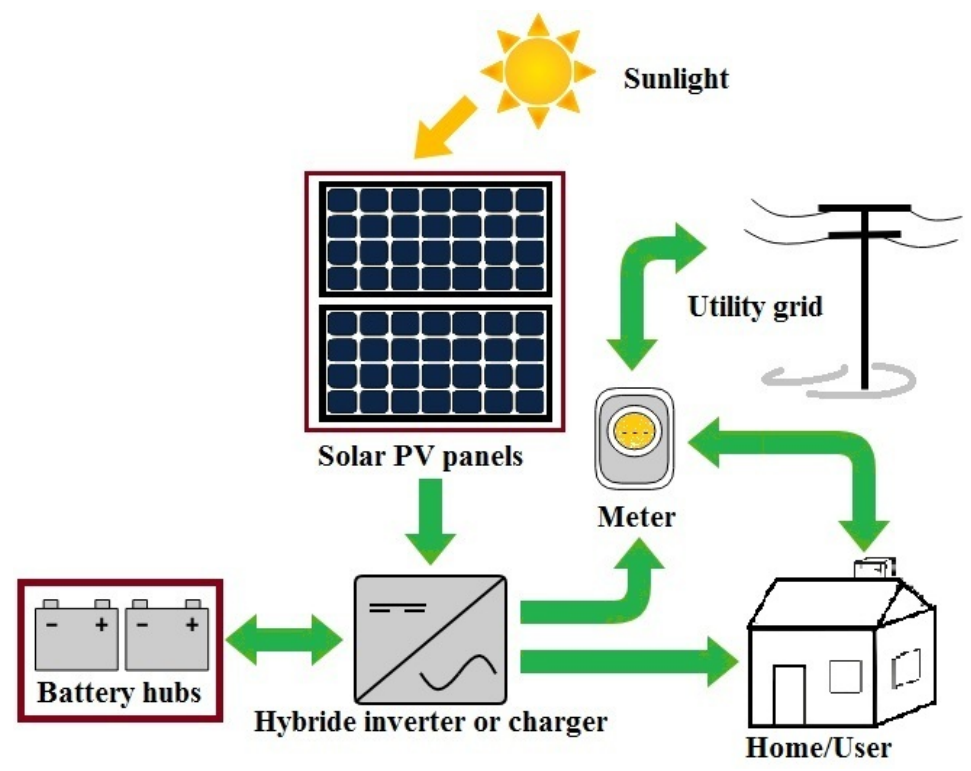

Fig. 1: Schematic diagram of a typical solar PV system.

The rooftop area hosting the PV system was surveyed in order to measure its main geometric dimensions and identify the N-S direction. This information was used for developing a rough 2D model of the rooftop. Furthermore, it was verified that the required power could be generated in the available area. The rough model 

built in Solid Works or Sketch up to have a basic idea on how the solar PV system will look after installation.

238 In this study, PVsyst simulations are carried out in order to evaluate the actual power generated by the existing 239 PV system and understand how the system itself performs after installation. This helps to optimize the current 240 configuration (i.e. the existing Design 1) into the newly developed Design 2. Simulation of how nearby objects 241 that create shadows on the panels which affect the energy generation process, allows losses to be quantified. 242 Simulation data served also to understand costs and economic benefits, thus helping the customer to plan the 243 project in the best way as possible. With the help of the 2D drawing, it can be determined (i) how to arrange PV 244 panels (i.e. in series or in parallel), (ii) the required number of inverters, and (iii) the panels string size yielding 245 the highest production of electric energy. The row spacing is determined from shading analysis: this is an 246 important step to avoid unwanted losses, which might occur if row spacing is too small or the available area is not properly utilized. Grid-connected PV systems are usually installed in urban sites where area availability may be a constraint. Our aim is to maximize energy output from the PV system while installing as many PV modules as possible in the available area. A formula for calculating the row spacing or shading distance is given in Eq. (1). Figures 2(a) and (b) represent the orientation of solar tilt and azimuth angle and illustrate the calculations required for the determination of shading angles, respectively.

$$
X=Y \frac{\cos \gamma}{\tan \varnothing}
$$
altitude at certain solar time.

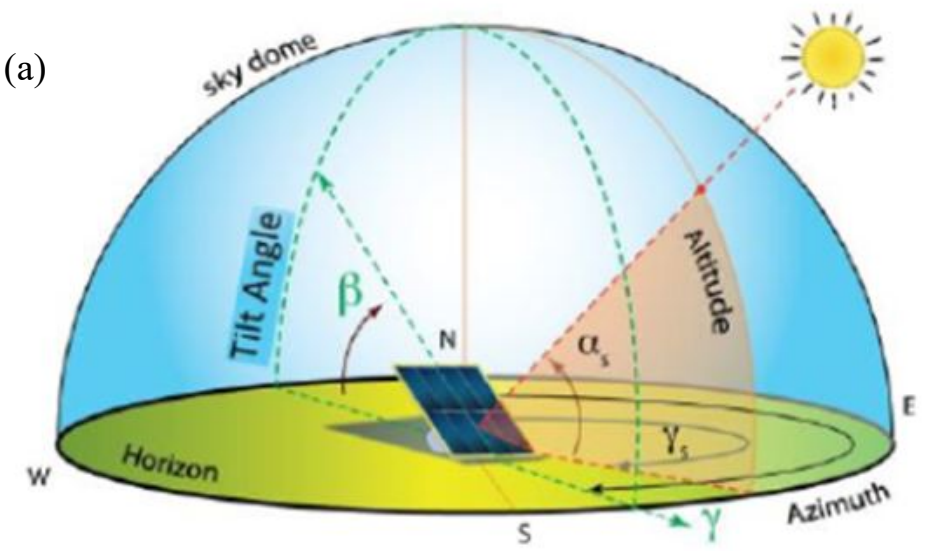


(b)

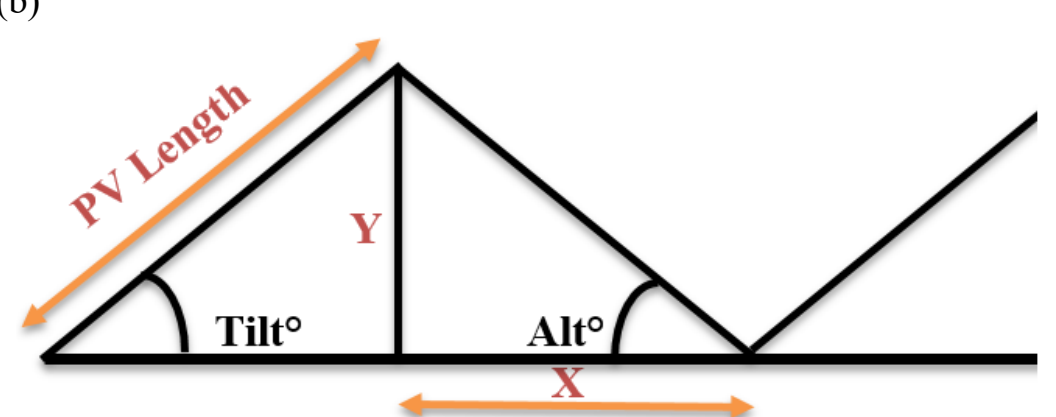

Fig. 2: (a) Orientation of solar tilt and azimuth angle, (b) Angles for shading calculation.

\subsection{Major system components and input parameters for these components}

The various components of a solar PV system should be selected according to customer's requirements, site location, and applications (Cardenas et al., 2017), (Dondariya et al., 2018) and (Al-Najideen and Alrwashdeh, 2017). PV modules convert sun light into electric energy. The existing plant (Design 1) includes 320W panels with dimensions $2 \mathrm{~m}$ x 1m; each panel weighs about $23 \mathrm{~kg}$. Solar charge controller helps to control voltage and current output from PV panels. This prevents battery overcharging, which may reduce battery life. However, in the present case, battery is not required as the designed PV system is a grid integrated PV system. Inverter converts DC current from the PV modules into AC current, which can easily be injected into the grid; this component is very important for an on-grid system design. Here, 4 inverters of $60 \mathrm{~kW}$ capacity each are used for the finalized PV system. For an off-grid system design, battery stores the DC power generated by the PV panels, which can be used later as desired. However, battery can only store a limited amount of energy and excess energy will be wasted. The Net Metering policy introduced by the Indian government allows PV system owners to inject excess energy generated by PV modules into the power grid and utility. Alternatively, government pays for the generated energy units as per a defined rate. Figure 3 (a) and (b) illustrate how net metering policy can benefit customers. The PV system is designed for supplying electricity to a certain number of appliances (e.g. illumination, $\mathrm{A} / \mathrm{C}$, industrial power or domestic appliances etc.). However, besides night-time hours when there is obviously no electricity generation, unpredictable weather events may reduce or even nullify the generation capacity of the PV system. Hence, auxiliary power sources (e.g. diesel generators) have to supply the required amount of energy. The introduction of net-metering policy and the on-grid system design option eliminate the need for auxiliary energy sources as the PV generated energy directly goes into the energy grid. 
(a) Generation and Consumption

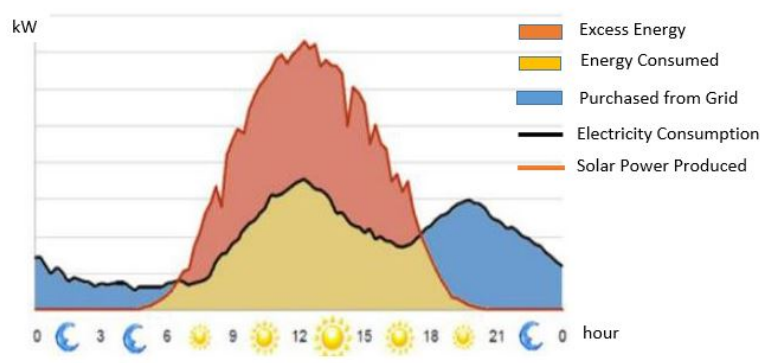

(b)

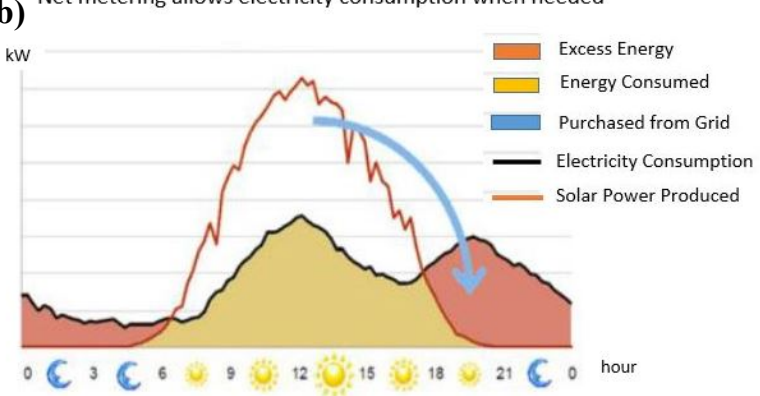
calculation of Return of Investment. developed Design 2.

Fig. 3: Energy distribution/storage of the PV system: (a) Without net metering, (b) With net metering.

\section{Technical specifications and economic analysis for the existing and newly developed PV plants}

\subsection{Basic calculations on installed capacity, number of panels and required area}

Customer's requirements are defined from the Electricity bill. The G.D. Naidu Block of the Vellore Institute of Technology (Vellore, India) required about $500 \mathrm{~kW}$ of installation but regulations only allowed about $50 \%$ of the sanction load to be installed. Since the sanction load (noted in the Electricity bill) was500 kW, a max of $250 \mathrm{~kW}$ of solar rooftop system could be installed. Table 1 illustrates the calculation of the number of solar PV panels, installed capacity, actual installed capacity and area required. The same data have been assumed for the newly

Table 1: Calculation of number of Solar PV panels, installed capacity and area required.

\begin{tabular}{|c|c|c|c|c|c|c|}
\hline $\begin{array}{l}\text { Total } \\
\text { Installed } \\
\text { Capacity }\end{array}$ & $\begin{array}{l}\text { Number of Panels } \\
\text { required }(320 \quad \mathrm{~W} \\
\text { each) }\end{array}$ & $\begin{array}{l}\text { Number of } \\
\text { panels } \\
\text { installed }\end{array}$ & $\begin{array}{l}\text { Actual } \\
\text { installed } \\
\text { capacity }\end{array}$ & $\begin{array}{l}\text { Area } \\
\text { required for } \\
\text { one panel } \\
\left(\mathrm{m}^{2}\right)\end{array}$ & $\begin{array}{l}\text { Area } \\
\text { required for } \\
\text { all panels } \\
\left(\mathrm{m}^{2}\right)\end{array}$ & $\begin{array}{l}\text { Actual area } \\
\text { available } \\
\left(\mathrm{m}^{2}\right)\end{array}$ \\
\hline $250 \mathrm{~kW}$ & $250000 / 320=781.25$ & 775 & $\begin{array}{l}775 * 320= \\
248000 \mathrm{~W}= \\
248 \mathrm{~kW}\end{array}$ & 2 & $\begin{array}{l}2 * 775= \\
1550\end{array}$ & 3800 \\
\hline
\end{tabular}


Table 2: Calculation of cost analysis and Return of investment.

\begin{tabular}{|c|c|c|c|c|c|c|c|c|}
\hline $\begin{array}{l}\text { Cost } \\
\text { of } \\
\text { pane } \\
1 \text { per } \\
\text { Watt }\end{array}$ & $\begin{array}{l}\text { Estimated } \\
\text { cost for } \\
\text { whole } \\
\text { plant }\end{array}$ & $\begin{array}{l}\text { Electric } \\
\text { ity per } \\
\text { year for } \\
1 \mathrm{~kW} \\
\text { installe } \\
\mathrm{d} \text { power }\end{array}$ & $\begin{array}{l}\text { Electric } \\
\text { ity per } \\
\text { day }\end{array}$ & $\begin{array}{l}\text { Money } \\
\text { saved } \\
\text { per year }\end{array}$ & $\begin{array}{l}\text { Electricity } \\
\text { bill cost } \\
\text { per unit }\end{array}$ & $\begin{array}{l}\text { Number of years } \\
\text { required for } \\
\text { return } \\
\text { investment }\end{array}$ & $\begin{array}{l}\text { Actual } \\
\text { Number } \\
\text { of years } \\
\text { required } \\
\text { for return } \\
\text { of } \\
\text { investme } \\
\text { nt due to } \\
\text { maintena } \\
\text { nce }\end{array}$ & $\begin{array}{l}\text { Rate of } \\
\text { Return } \\
\text { of } \\
\text { investm } \\
\text { ent }\end{array}$ \\
\hline $\begin{array}{l}40 \\
\text { rupe } \\
\text { es }\end{array}$ & $\begin{array}{l}40 * 248000 \\
=₹ \\
9,920,000\end{array}$ & $\begin{array}{l}1500 \\
\text { units }\end{array}$ & $\begin{array}{l}1500 / 3 \\
65=4.2 \\
\text { units/pe } \\
\text { r day }\end{array}$ & $\begin{array}{l}\text { ₹ } \\
2,604,0 \\
00\end{array}$ & $\begin{array}{l}\text { ₹ } 7 \text { per } \\
\text { unit } \\
(248 * 150 \\
0 * 7=\text { ₹ } \\
2,604,000 \\
)\end{array}$ & $\begin{array}{l}9,920,000 / 2,604 \\
, 000=3.8 \text { years }\end{array}$ & 4 years & $1 / 4=25 \%$ \\
\hline
\end{tabular}

306

Since the lifetime of a PV module is at least 25 years, after the 4 years of ROI, savings on the electricity bill at least goes on for next 21 years. Costs related to changes of some components were not estimated to impact significantly on ROI. ROI calculations are the same for both the existing Design 1 and the proposed Design 2.

\subsection{Average money saving on electricity bill granted by solar energy}

As mentioned before, Table 3 represents the calculations of monthly savings in electricity bill.

Table 3: Calculation on monthly saving on electricity bill (Thakur and Chakraborty, 2018).

\begin{tabular}{|l|l|l|}
\hline Money saved per year & Monthly saving on electricity bill & Percentage of saving \\
\hline ₹ $2,604,000$ & $₹ 2,604,000 / 12=₹ 217000$ & $70 \%$ \\
\hline
\end{tabular}

\subsection{Orientation of PV panels}

The G.D. Naidu block of the Vellore Institute of Technology is located at $180^{\circ}$ azimuth (i.e. $180^{\circ}$ slants from north direction). Since the inclination of the rooftop is about $0^{\circ}$, the total inclination of the PV modules of the existing plant also is $22^{\circ}$. The new Design 2 developed in this study has the same orientation as the existing Design 1 plant and $22^{\circ}$ tilt because the latitude of Vellore is around $23^{\circ}-30^{\circ}$. The orientation of the panels has been selected such as to maximize the output power, consistently with the building orientation and technical requirements. The orientation, tilt, azimuth angles and the allocated number of panels are the same for both the existing Design 1 and the proposed Design 2 (South orientation). 
328 Figures 4(a) and 4(b), respectively, show the 2D drawings of the existing PV system Design 1 and the proposed PV system Design 2. The Sketch Up software was used to draw these schemes. The 2D design gives important information on where panels should to be placed, North-South direction, and available area and nearby objects (which will be useful for shading analysis). The 2D schemes help to select the best options for the customer, optimize energy output by properly locating panels. All these factors contribute to the selection of the most economical design.
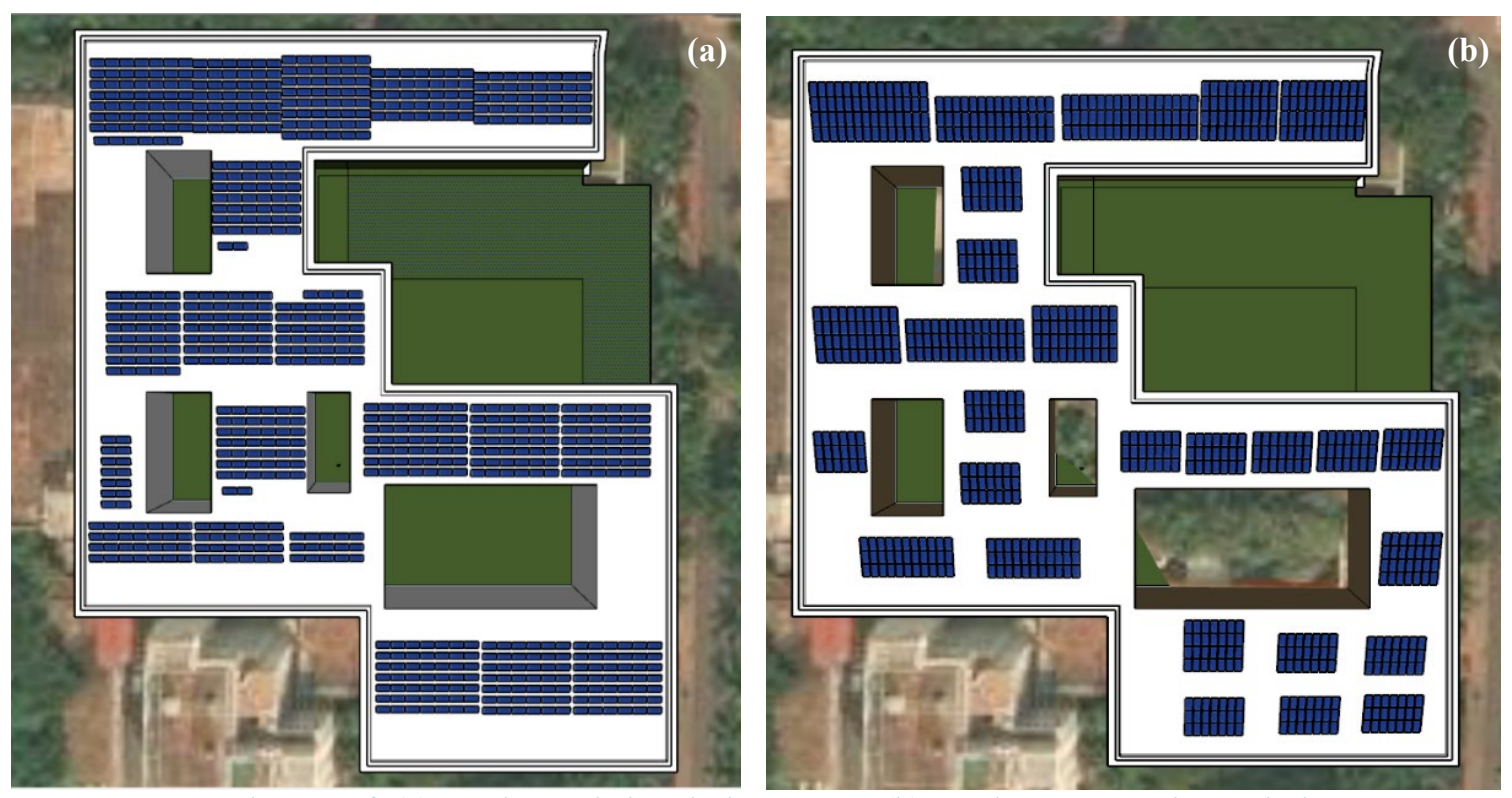

Fig. 4: 2D schemes of: (a) $248 \mathrm{~kW}$ existing design type 1; (b) $248 \mathrm{~kW}$ proposed new design type 2.

\subsection{D Scenes of the PV systems in the PV syst software}

A 3D scene for both designs 1 and 2 is created in the PVsyst software environment. This operation allows performing shading analysis for each selected design and correctly predicting the potential of the corresponding system. Figures 5(a) and 5(b), respectively, show the PVsyst 3D scenes for designs 1 and 2. The 3D scenes are defined according to selected orientation and azimuth parameters and the number of PV panels. The PV panels are denoted by the blue color and Fig. 5(c) shows a real photograph of the existing Design 1. It can be seen from Figure 5 that nearby buildings will not shade the PV panels as they are either shorter or far away to cause any problem. However, shading of PV panels may be caused by the presence of adjacent panels. 

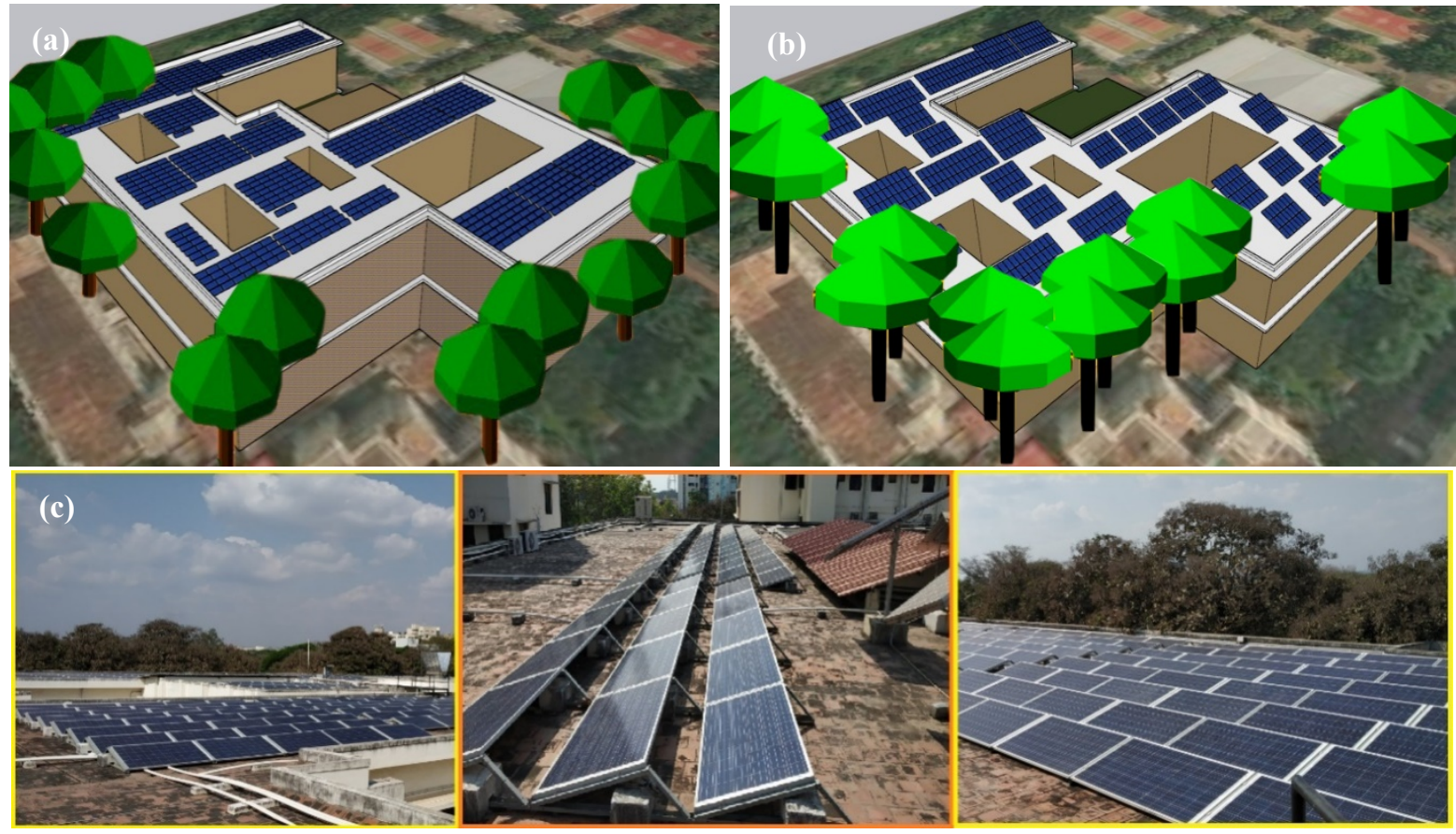

Fig. 5: (a) 3D scene for $248 \mathrm{~kW}$ system Design 1; (b) 3D Scene for $248 \mathrm{~kW}$ system Design 2; (c) Photograph of the existing plant Design 1.

\section{Results and Discussions}

As mentioned in the previous sections, the potential of the $248 \mathrm{~kW}$ installed PV plant was analyzed using the PVsyst software. The software can evaluate the energetic efficiency of the PV system; perform output/input comparisons, loss analysis, shading analysis etc. The simulations run in this study covered all days of a dummy year, considering average values of global radiation and horizontal irradiation, temperature, amount of rain precipitations and other parameters that may cause deviations from the planned energy output. Here, the meteorological data collected for Vellore (Tamil Nadu, India) were given in input to the software in order to carry out highly accurate simulations. Designs 1 and 2 were compared under various aspects to find which design is better. The existing Design 1 was progressively perturbed by rearranging panels so to obtain Design 2. For that purpose, Design 1 was iteratively perturbed as follows: the positions of PV panels were modified by considering 5 panels in each iteration. This process terminated as soon as the energy injected to grid increased by less than $0.01 \%$ with respect to the previous iteration. Such a strategy was very accurate because the design perturbation in a single iteration regarded the $0.645 \%$ of the total number of PV panels (i.e. $5 / 775$ panels) while the threshold for stopping the process was only $0.01 \%$, almost two orders of magnitude smaller than the selected design perturbation. An optimization-based selection process identified the 5 panels to be perturbed in each iteration. This approach allows the potential of a system to be fully understood. A proper risk analysis was also performed by PVsyst to make sure that full potential of system would be properly used. 
369 Tables 4 (a) and 4(b), respectively, summarize the performance of the existing Design 1 and the newly developed

370 Design 2 compared in this study. The tables list data relative to global horizontal irradiation, global incident irradiation, ambient temperature, effective global irradiation, effective energy generated by the PV array, energy introduced into grid and global plant efficiency. Monthly values are reported for each quantity. Energy values are summed over the 12 months while ambient temperature and plant efficiency are averaged over the one year period. It can be easily seen from the data listed in the tables that the new Design 2 outperforms the existing Design 1. In fact, the amount of energy that would be introduced into the grid by Design 2 over one year is $40 \mathrm{MWh}$ higher than its counterpart for Design 1: 387.59 vs. only 343.89 MW (i.e. about 13\% improvement). The performance Ratio (PR) of a plant for a period of time is energy measured $(\mathrm{kWh}) /\left(\right.$ Irradiance $\left(\mathrm{kWh} / \mathrm{m}^{2}\right)$ on the panel $\times$ Active area of PV module $\left(\mathrm{m}^{2}\right) \times \mathrm{PV}$ module efficiency). PR measures the performance of a PV system taking into account environmental factors (temperature, irradiation, climate changes etc.). The average performance ratio is measured based on the average of 12 months. Table 4(a) and (b) show that the average performance ratio increases from

Table 4: (a) Energy input/output balance and performance for Design 1 (existing PV plant).

\begin{tabular}{|c|c|c|c|c|c|c|c|c|c|c|c|c|c|}
\hline 号 & $\begin{array}{l}\vec{\Xi} \\
\stackrel{\Xi}{\Xi} \\
\text { 奇 }\end{array}$ & 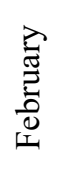 & $\begin{array}{l}\frac{\pi}{0} \\
\sum^{ \pm}\end{array}$ & 容 & $\stackrel{\vec{\Sigma}}{\Sigma}$ & $\Xi$ & $\stackrel{\lambda}{\Xi}$ & $\begin{array}{l}\vec{w} \\
\vec{E} \\
\vec{Z} \\
\vec{Z}\end{array}$ & 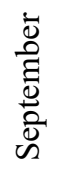 & $\begin{array}{l}\overline{0} \\
\stackrel{0}{0} \\
\dot{0} \\
0\end{array}$ & $\begin{array}{l}\overline{0} \\
\text { है } \\
\text { ठठ } \\
z\end{array}$ & 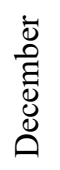 & $\begin{array}{l}\text { 吾 } \\
\text { 宗 }\end{array}$ \\
\hline $\begin{array}{l}\text { Horizontal global irradiation } \\
\qquad\left(\mathrm{kWh} / \mathrm{m}^{2}\right)\end{array}$ & $\stackrel{\infty}{\infty}$ & ㅇ. & $\begin{array}{l}\stackrel{0}{0} \\
\stackrel{0}{\varrho}\end{array}$ & $\stackrel{\infty}{\stackrel{\infty}{2}}$ & $\underset{\infty}{\infty}$ & $\begin{array}{l}\stackrel{0}{0} \\
\stackrel{\leftrightarrow}{n}\end{array}$ & $\stackrel{\infty}{\underline{n}}$ & $\begin{array}{l}\forall \dot{0} \\
\stackrel{\leftrightarrow}{n}\end{array}$ & $\underset{\ddot{n}}{\ddot{n}}$ & $\begin{array}{l}\infty \\
\dot{\delta} \\
\dot{J}\end{array}$ & $\stackrel{\overbrace{}}{\check{\Xi}}$ & $\stackrel{m}{m}$ & $\tilde{n}$ \\
\hline $\begin{array}{l}\text { Horizontal diffuse irradiation } \\
\qquad\left(\mathrm{kWh} / \mathrm{m}^{2}\right)\end{array}$ & $\frac{\infty}{n}$ & $\underset{\text { in. }}{\text { in }}$ & 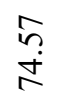 & $\begin{array}{l}\hat{\sigma} \\
\substack{\infty \\
\infty}\end{array}$ & $\begin{array}{l}\infty \\
\infty \\
\infty \\
\infty\end{array}$ & $\begin{array}{l}0 \\
\dot{\infty} \\
\dot{\infty}\end{array}$ & $\underset{\dot{q}}{\stackrel{?}{\infty}}$ & $\begin{array}{l}\stackrel{\nabla}{\bullet} \\
\stackrel{0}{n}\end{array}$ & $\underset{\sim}{\ddot{n}}$ & 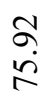 & 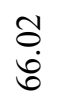 & $\frac{\infty}{\dot{\sigma}}$ & $\begin{array}{l}\substack{6 \\
+\\
\infty \\
\infty} \\
\infty\end{array}$ \\
\hline $\begin{array}{c}\text { Ambient temperature } \\
\left({ }^{\circ} \mathrm{C}\right)\end{array}$ & 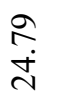 & $\begin{array}{l}\text { बे } \\
\text { ते }\end{array}$ & $\begin{array}{l}\infty \\
\infty \\
\infty \\
\sim\end{array}$ & ஜே. & $\frac{\text { I }}{\dot{m}}$ & 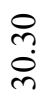 & 官 & $\vec{\sim}$ & $\begin{array}{l}\infty \\
\substack{n \\
i \\
\infty}\end{array}$ & $\stackrel{\substack{n \\
ָ}}{\stackrel{n}{n}}$ & $\begin{array}{l}\text { ते } \\
\text { iे }\end{array}$ & $\begin{array}{l}\stackrel{i}{+} \\
\stackrel{+}{+}\end{array}$ & $\underset{\sim}{\stackrel{\sigma}{\sim}}$ \\
\hline $\begin{array}{l}\text { Global incident irradiation } \\
\qquad\left(\mathrm{kWh} / \mathrm{m}^{2}\right)\end{array}$ & $\stackrel{m}{\stackrel{m}{2}}$ & 今. & कें & $\stackrel{+}{+}$ & $\begin{array}{l}\stackrel{0}{\dot{b}} \\
\dot{6}\end{array}$ & $\begin{array}{l}\stackrel{\dot{n}}{n} \\
\ddot{n}\end{array}$ & $\underset{n}{\dddot{n}}$ & $\stackrel{n}{\sharp}$ & $\begin{array}{l}\bar{i} \\
\tilde{n}\end{array}$ & $\begin{array}{l}\stackrel{0}{\circ} \\
\stackrel{n}{n}\end{array}$ & 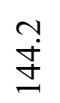 & 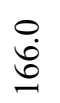 & $\begin{array}{l}0 \\
\stackrel{0}{i} \\
\text { a }\end{array}$ \\
\hline $\begin{array}{l}\text { Effective global irradiation } \\
\qquad\left(\mathrm{kWh} / \mathrm{m}^{2}\right)\end{array}$ & $\begin{array}{l}n \\
\tilde{c} \\
\underline{6}\end{array}$ & $\underset{\infty}{\infty}$ & $\begin{array}{l}a \\
\ddot{\infty}\end{array}$ & $\frac{n}{6}$ & 守 & $\stackrel{\check{\sigma}}{\stackrel{\Xi}{\sigma}}$ & $\stackrel{\circ}{\stackrel{\infty}{=}}$ & 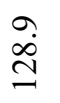 & $\underset{m}{\stackrel{0}{m}}$ & 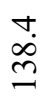 & $\overrightarrow{\widetilde{I}}$ & $\underset{n}{a}$ & $\stackrel{\stackrel{n}{m}}{\stackrel{c}{=}}$ \\
\hline $\begin{array}{l}\text { Effective energy at the output } \\
\text { of the array }(\mathrm{MW} / \mathrm{h})\end{array}$ & กี & 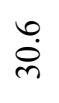 & 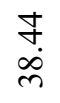 & $\begin{array}{l}0 \\
\ddot{n} \\
\ddot{n}\end{array}$ & $\begin{array}{l}\infty \\
\infty \\
\infty \\
\infty\end{array}$ & 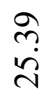 & $\ddot{n}$ & 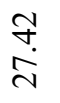 & $\begin{array}{l}\infty \\
\infty \\
\infty \\
\infty\end{array}$ & 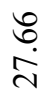 & $\begin{array}{l}\mathbb{U} \\
\text { तें }\end{array}$ & $\stackrel{\text { i }}{\text { i }}$ & 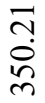 \\
\hline $\begin{array}{l}\text { Energy injected into grid } \\
(\mathrm{MWh})\end{array}$ & $\begin{array}{l}\ddot{0} \\
\stackrel{\sim}{i}\end{array}$ & 它 & $\underset{m}{\infty}$ & 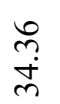 & m. & $\begin{array}{l}\check{n} \\
\grave{d}\end{array}$ & $\vec{a}$ & مे & 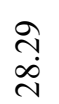 & $\begin{array}{l}\underset{\sim}{\pi} \\
\stackrel{n}{\pi}\end{array}$ & $\stackrel{ \pm}{\sim}$ & 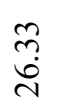 & $\begin{array}{l}\infty \\
\dot{p} \\
\dot{m}\end{array}$ \\
\hline
\end{tabular}


Performance ratio

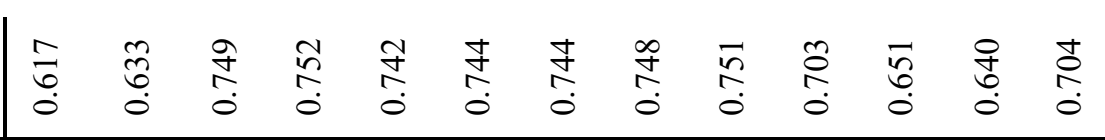

Table 4: (b) Energy input/output balance and performance for Design 2 (newly developed PV plant).

\begin{tabular}{|c|c|c|c|c|c|c|c|c|c|c|c|c|c|}
\hline $\begin{array}{l}n \\
\stackrel{0}{0} \\
\Sigma\end{array}$ & 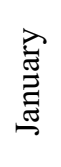 & 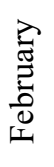 & 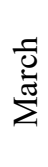 & $\bar{Z}$ & $\sum_{i}^{\vec{J}}$ & $\stackrel{\Xi}{\Xi}$ & $\stackrel{\gtrsim}{\Xi}$ & 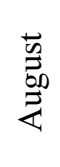 & 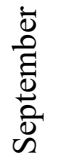 & $\begin{array}{l}\dot{\overline{0}} \\
\stackrel{0}{0} \\
\stackrel{0}{0}\end{array}$ & $\begin{array}{l}\dot{\bar{\Xi}} \\
\text { है } \\
\overline{0} \\
0 \\
z\end{array}$ & 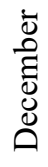 & 㞼 \\
\hline $\begin{array}{l}\text { Horizontal global irradiation } \\
\qquad\left(\mathrm{kWh} / \mathrm{m}^{2}\right)\end{array}$ & $\stackrel{\infty}{\infty}$ & $\stackrel{0}{\sigma}$ & $\begin{array}{l}0 \\
0 \\
0\end{array}$ & $\stackrel{\infty}{\infty}$ & 今゙ & $\begin{array}{l}\mathscr{b} \\
\stackrel{+}{n}\end{array}$ & $\stackrel{\infty}{n}$ & $\begin{array}{l}\forall \\
\stackrel{\sim}{n}\end{array}$ & $\stackrel{\nabla}{\ddot{n}}$ & $\begin{array}{l}\infty \\
\dot{0} \\
\dot{+}\end{array}$ & $\stackrel{ヘ}{\check{N}}$ & $\stackrel{m}{n}$ & ñ \\
\hline $\begin{array}{l}\text { Horizontal diffuse irradiation } \\
\qquad\left(\mathrm{kWh} / \mathrm{m}^{2}\right)\end{array}$ & $\frac{\infty}{n}$ & is & 战 & $\underset{\substack{\sigma \\
\infty}}{\infty}$ & $\begin{array}{l}\infty \\
\infty \\
\infty \\
\infty\end{array}$ & $\begin{array}{l}\Re \\
\stackrel{\infty}{\infty}\end{array}$ & $\underset{\infty}{\stackrel{\wp}{+}}$ & 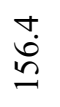 & $\stackrel{\nabla}{\tilde{n}}$ & $\stackrel{2}{a}$ & $\begin{array}{l}\text { Oे } \\
\text { రి }\end{array}$ & $\frac{\infty}{\infty}$ & $\begin{array}{l}\text { } \\
\dot{+} \\
\infty \\
\infty\end{array}$ \\
\hline $\begin{array}{l}\text { Ambient temperature } \\
\qquad\left({ }^{0} \mathrm{C}\right)\end{array}$ & 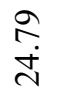 & aे & $\stackrel{n}{\infty}$ & $\stackrel{n}{\stackrel{n}{a}}$ & $\frac{⿱ 亠 䒑 十}{\dot{m}}$ & 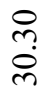 & $\stackrel{\substack{0 \\
0}}{0}$ & ๙ุ่ & $\begin{array}{l}\stackrel{i}{n} \\
\stackrel{\infty}{N}\end{array}$ & $\frac{n}{n}$ & ๙ุ) & 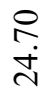 & à \\
\hline $\begin{array}{l}\text { Global incident irradiation } \\
\qquad\left(\mathrm{kWh} / \mathrm{m}^{2}\right)\end{array}$ & ๙்ุ & $\stackrel{0}{\circ}$ & ֻุ & ণִ & $\underset{0}{6}$ & $\stackrel{n}{n}$ & $\stackrel{n}{n}$ & ڤి & กิ่ & $\stackrel{a}{n}$ & $\stackrel{m}{\mathscr{g}}$ & $\underset{\nabla}{\stackrel{\nabla}{\sigma}}$ & $\begin{array}{l}n \\
\infty \\
a\end{array}$ \\
\hline $\begin{array}{l}\text { Effective global irradiation } \\
\qquad\left(\mathrm{kWh} / \mathrm{m}^{2}\right)\end{array}$ & $\stackrel{m}{\infty}$ & $\stackrel{n}{\infty}$ & $\stackrel{0}{\dot{j}}$ & $\stackrel{n}{n}$ & 它 & $\stackrel{a}{\infty}$ & 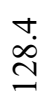 & $\vec{\infty}$ & $\begin{array}{l}0 \\
\dot{J} \\
\dot{J}\end{array}$ & $\stackrel{\infty}{\underset{\Xi}{ \pm}}$ & $\begin{array}{l}0 \\
\stackrel{0}{0} \\
\stackrel{0}{=}\end{array}$ & $\begin{array}{l}\hat{0} \\
\stackrel{n}{n}\end{array}$ & $\underset{⿱ 亠 凶}{\grave{\infty}}$ \\
\hline $\begin{array}{l}\text { Effective energy at the output } \\
\text { of the array }(\mathrm{MW} / \mathrm{h})\end{array}$ & 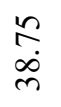 & $\underset{\substack{\infty \\
\text { m }}}{\infty}$ & $\stackrel{+}{\stackrel{+}{*}}$ & $\underset{m}{\stackrel{m}{0}}$ & $\begin{array}{l}\infty \\
\dot{n} \\
\sim\end{array}$ & $\bar{n}$ & $\stackrel{\infty}{\stackrel{N}{N}}$ & ๙ุ. & $\stackrel{n}{\dddot{m}}$ & $\stackrel{\infty}{\stackrel{\infty}{m}}$ & $\frac{0}{a}$ & 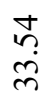 & $\begin{array}{l}\hat{0} \\
\hat{n} \\
\hat{m}\end{array}$ \\
\hline $\begin{array}{l}\text { Energy injected into grid } \\
\text { (MWh) }\end{array}$ & à & $\stackrel{n}{\stackrel{n}{n}}$ & $\stackrel{n}{n}$ & $\begin{array}{l}\bar{\sigma} \\
\dot{0} \\
m\end{array}$ & ஸे & $\begin{array}{l}\text { } \\
\stackrel{0}{0} \\
\stackrel{N}{0}\end{array}$ & $\begin{array}{l}\stackrel{8}{\infty} \\
\stackrel{0}{\sim} \\
\text {. }\end{array}$ & $\begin{array}{l}\stackrel{\Re}{\stackrel{\infty}{\sim}} \\
\stackrel{\infty}{0}\end{array}$ & $\hat{\imath}$ & $\begin{array}{l}\text { Oे } \\
\dot{0} \\
\text { ’ }\end{array}$ & $\begin{array}{l}\text { రై } \\
\infty \\
\stackrel{\sim}{N}\end{array}$ & $\begin{array}{l}\tilde{a} \\
\tilde{n}\end{array}$ & $\begin{array}{l}\hat{n} \\
\hat{\infty} \\
n\end{array}$ \\
\hline Performance ratio & $\begin{array}{l}\infty \\
\stackrel{0}{2} \\
\dot{0}\end{array}$ & $\frac{n}{\hat{\sigma}}$ & 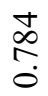 & 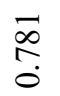 & $\hat{\hat{N}}$ & $\underset{\hat{0}}{\stackrel{\infty}{\infty}}$ & $\begin{array}{l}\infty \\
\stackrel{\infty}{\sim} \\
\dot{0}\end{array}$ & $\frac{2}{\stackrel{\infty}{\hat{0}}}$ & $\begin{array}{l}0 \\
\stackrel{\infty}{T} \\
0\end{array}$ & $\frac{n}{2}$ & $\begin{array}{l}0 \\
\stackrel{0}{\infty} \\
\dot{0}\end{array}$ & $\begin{array}{l}\stackrel{\circ}{\circ} \\
\infty \\
\dot{0}\end{array}$ & $\bar{a}$ \\
\hline
\end{tabular}

386

\subsection{Loss diagrams of Designs 1 and 2}

Figures 6 and 7 show the loss diagrams for Design 1 and Design 2, respectively. Each diagram shows the incident irradiation energy and the resulting energy flow, including all possible losses that may occur during the conversion process from solar energy to electric energy. By subtracting all the losses quantified by the loss diagram from the energy falling onto the panel, it is possible to determine how much of this energy is being converted into electricity. It appears that the PV plant can convert into electric energy only about $12-18 \%$ of the solar energy. The flow diagrams of Figures 6 and 7 give information on the energy losses occurring in the conversion process, specifying the location of each loss and the corresponding impact on the energy conversion efficiency. This helps to understand which components or any other factors have to be targeted in order to maximize energy production. The comparison of loss diagrams obtained for Design 1 and Design 2 clearly indicates that the existing Design 1 has more losses, mainly caused by shading effects. 

reduction of the irradiance really reaching the PV cells surface with respect to the irradiance that would reach the

400 PV cell surface under normal incidence. This reduction is mainly due to reflections on the glass cover, which 401 increases with the incidence angle $\mathrm{kWp}$ is the peak power of a PV system or panel, where $\mathrm{kWp}$ stands for kilowatt

402 'peak' of a system. The power is calculated using a standardized test for panels across all manufacturers to ensure 403 that the values listed can be fairly compared. The test conditions for module performance are generally rated under

404 Standard Test Conditions (STC): irradiance of $1000 \mathrm{~W} / \mathrm{m}^{2}$, a module temperature of $25^{\circ} \mathrm{C}$ and a solar spectrum of AM 1.5. The maximum power point is denoted as MPP.

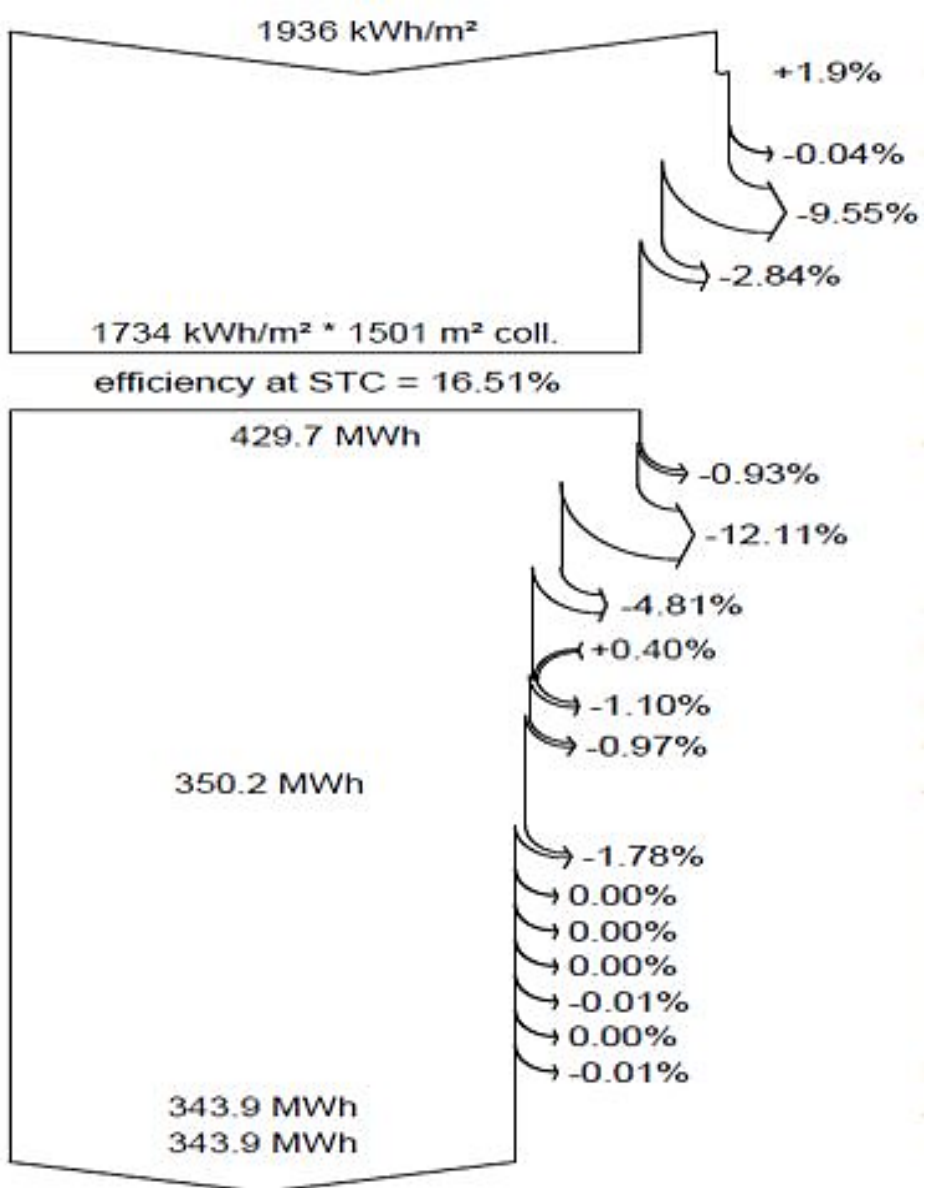

Horizontal Global Irradiation Global Incident Radiation in collector plane

Global incident radiation below threshold Near shadings: Irradiance Loss

IAM Factor on Global Effective irradiance on collectors PV conversion Array nominal energy (at STC eff.) PV Loss due to irradiance level PV loss due to temperature Shadings: Electrical Loss, sheds3 strings in width Module quality loss

Mismatch loss, modules and strings Ohmic wiring loss Array virtual energy at MPP

Inverter loss during operation (effic.) Inverter loss over nominal inv. Power Inverter loss due to max. Input current Inverter loss over nominal inv. Voltage Inverter loss due to power threshold Inverter loss due to voltage threshold Night consumption

Available energy at inverter output Energy injected into grid 


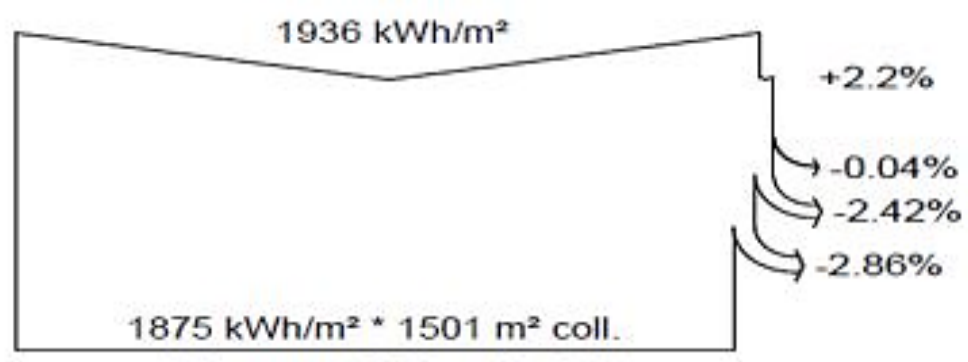

efficiency at STC $=16.51 \%$

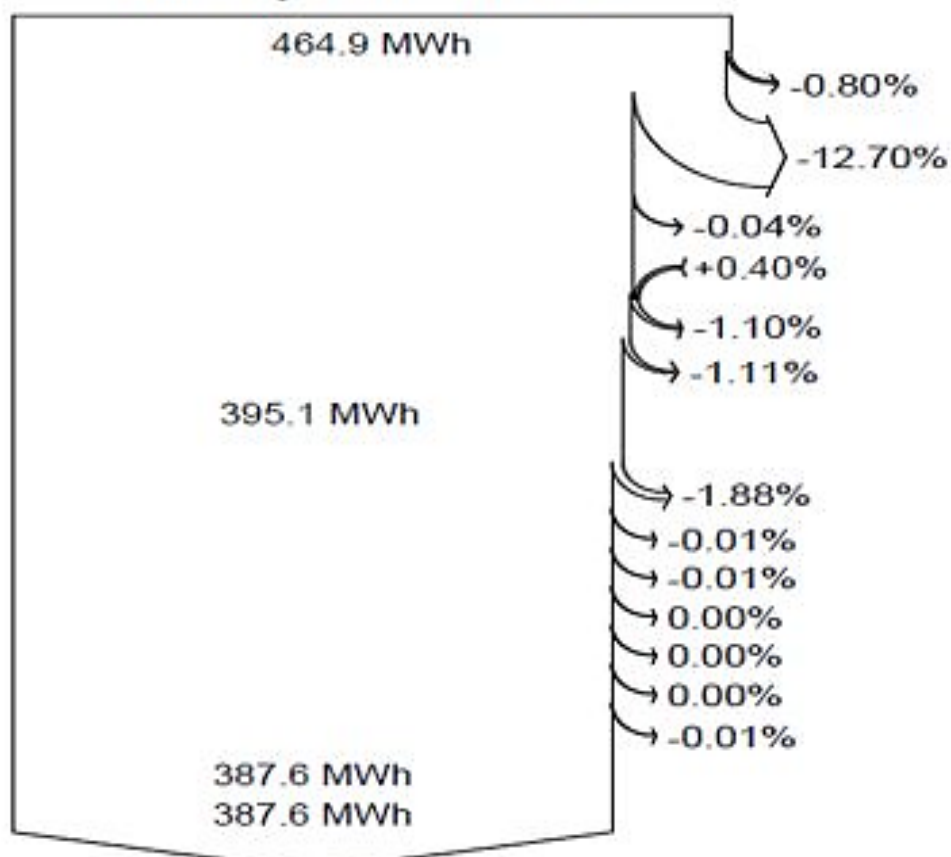

Horizontal Global Irradiation

Global Incident Radiation in collector plane

Global incident radiation below threshold

Near shadings: Irradiance Loss

IAM Factor on Global

Effective irradiance on collectors

$\mathrm{PV}$ conversion

Array nominal energy (at STC eff.)

PV Loss due to irradiance level

PV loss due to temperature

Shadings: Electrical Loss, sheds3 strings in width

Module quality loss

Mismatch loss, modules and strings

Ohmic wiring loss

Array virtual energy at MPP

Inverter loss during operation (effic.) Inverter loss over nominal inv. Power Inverter loss due to max. input current Inverter loss over nominal inv. Voltage Inverter loss due to power threshold Inverter loss due to voltage threshold Night consumption

Available energy at inverter output Energy injected into grid

Fig. 7: Energy conversion process of loss diagram for Design 2.

\subsection{Normalized energy production}

Figures 8(a) and (b) show the performance ratio of Design 1 and Design 2, respectively. For both designs, the lowest amounts of energy per day per $\mathrm{kWp}$ are produced in July to December because of the rainy and winter season in Vellore (Tamil Nadu) India. A nearly zero energy production of the PV system is obviously observed under rainy weather conditions. Furthermore, after the rain, water leaves markings on the PV panels that contribute to reduce the energy production. In the winter season, there are less sunlight hours: the amount of generated energy decreases by a great extent but remains higher than its counterpart for the rainy season. Energy generation per day, per kWp has been found highest in month of March, April and May due to the brightest sun and clear sky, whereas in June, January and February it has been seen moderate production of energy. These weather conditions are the ideal scenario for achieving the best performance of a solar PV system for electric power generation. 

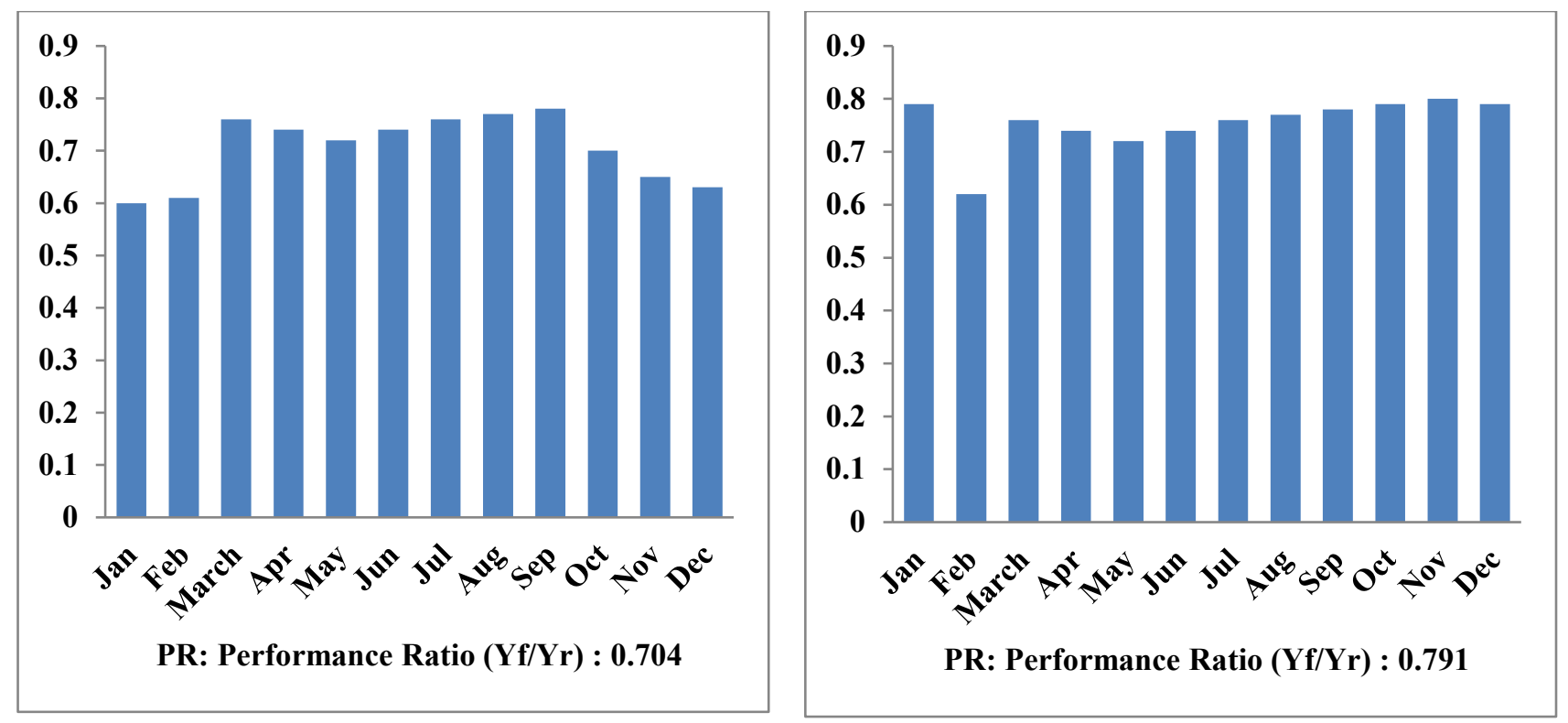

Fig. 8: (a) Performance ratio of Design 1, (b) Performance ratio of Design 2.

\section{8}

479

480

481

482

483

\subsection{Daily system output energy}

Figures 9(a) and 9(b) show the daily output energy (i.e. the energy injected into the grid) throughout the year for

Design 1 and Design 2, respectively. The lowest amounts of injected energy are seen over June-September for both designs. This is strictly correlated to the fact that global irradiation is very small because in the rainy season clouds cover the sun and do not allow the sun rays to fall on the PV panels. Furthermore, rain drops on the panels and the dirt remains attached to the panel surface, thus reducing the energy conversion efficiency. Hence, the amount of output energy is higher for the winter season than for rainy season. The generated energy is maximum between March and May, when the sun is brightest and directly above our head.

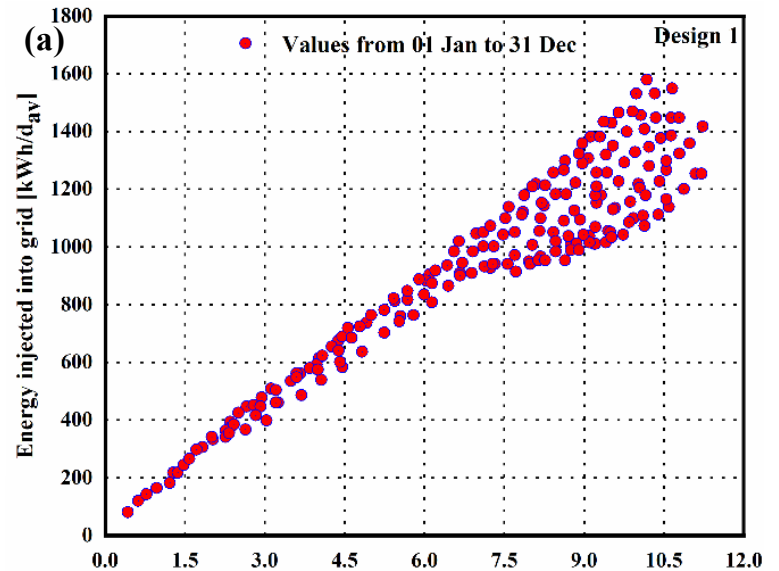

Global incident radiation in collector plane $\left[\mathrm{kWh} / \mathrm{m}^{2}\right.$.day $]$

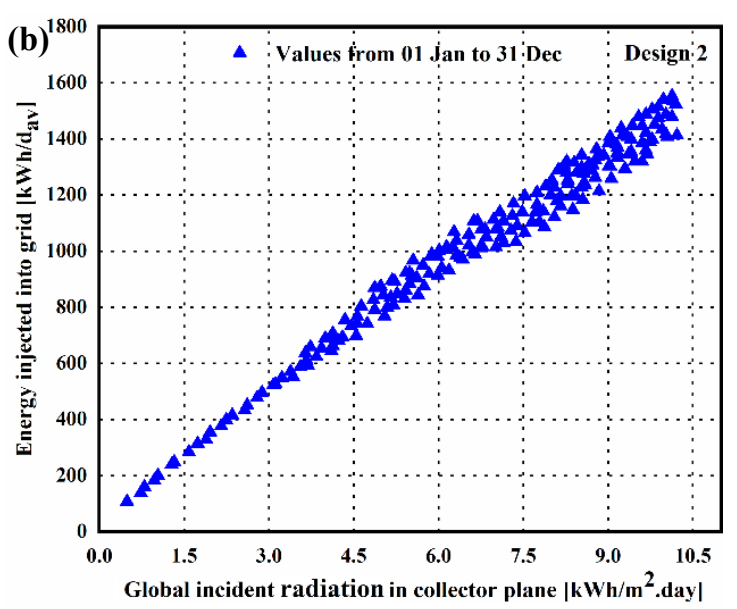

Fig. 9: (a) Daily system output energy for Design 1; (b) Daily system output energy for Design 2. 


\subsection{Shadow analysis}

493 Shadow analysis is a very important part in the design process of a PV system. Nearby objects which may cause panel shading are identified. Panels on shading offer a lower power output. Since PV panels are connected in series so as to form strings, when a single panel is on shading its current output decreases and becomes the lowest current output in the string. Thus, shading reduces the output of the whole string, which is no longer utilized at its full potential. The PVsyst software allows obtaining a design solution with the lowest shading loss as possible, thus getting the maximum benefits from solar irradiation. Shading analysis for both Design 1 and Design 2 were carried out for the following three critical dates:

- $21^{\text {st }}$ March 2019 - Spring Equinox;

- $21^{\text {st }}$ June 2019 - Summer Solstice (Earth has its maximum tilt towards sun);

-In $21^{\text {st }}$ Dec 2019 - Winter Solstice (Earth has its maximum tilt away from the sun), the minimum possible shading analyses performed for the two designs. The analyses refer to $21^{\text {st }}$ December 2019 at 2:30p.m. A clear improvement can be seen for the proposed Design 2 with respect to the existing Design 1.
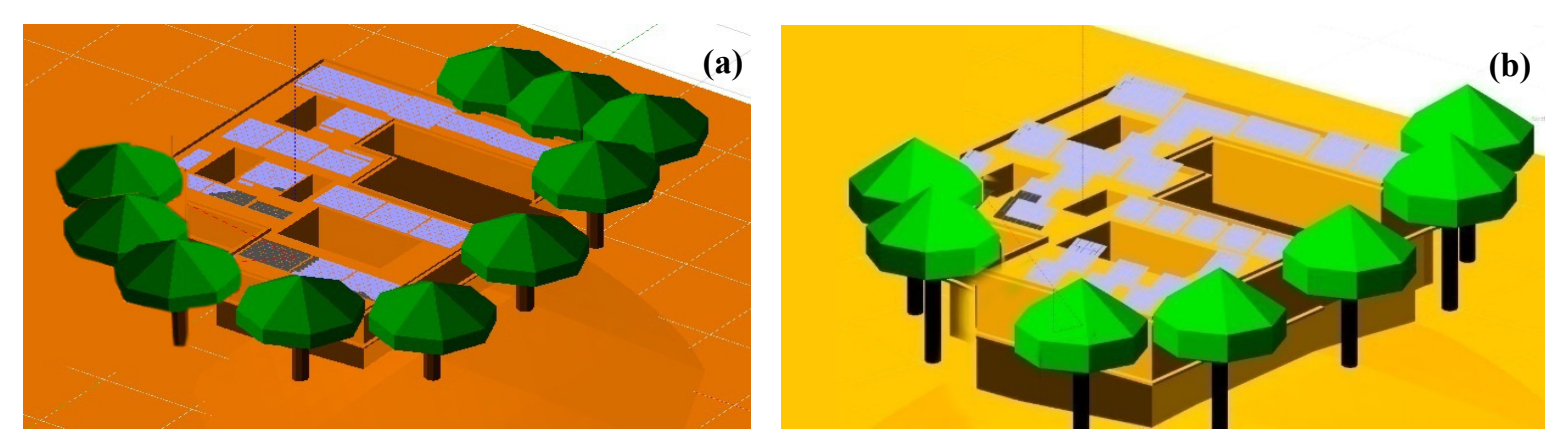

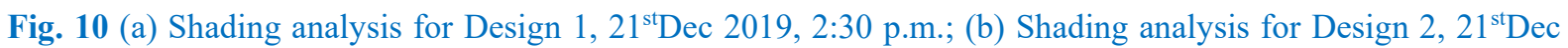
2019, 2:30 p.m.

\subsection{Emissions saved}

Table 5 shows the assumptions made for evaluating emissions per unit of electricity. Table 6 represents the emissions per year in the case of Design 1 and Design 2.

Table 5: Emissions per unit of electricity

\begin{tabular}{|c|c|c|c|}
\hline \multirow{2}{*}{ Sl. No. } & \multicolumn{3}{|c|}{ Emissions per unit of electricity } \\
\cline { 2 - 4 } & $\mathrm{CO}_{2} \mathrm{~kg} / \mathrm{kWh}$ & $\mathrm{SO}_{2} \mathrm{~g} / \mathrm{kWh}$ & $\mathrm{NO} \mathrm{g} / \mathrm{kWh}$ \\
\hline Last decade & $0.91-0.95$ & $6.94-7.2$ & $4.22-4.38$ \\
\hline $\begin{array}{c}\text { Assumed in Current } \\
\text { study }\end{array}$ & 0.95 & 7.2 & 4.38 \\
\hline
\end{tabular}


Table 6: Calculation of emissions per year for Design 1 and Design 2.

517

\begin{tabular}{|c|c|c|c|}
\hline \multirow[t]{2}{*}{ Number of design } & \multicolumn{3}{|c|}{ Emissions per year } \\
\hline & $\mathrm{CO}_{2}$ & $\mathrm{SO}_{2}$ & $\mathrm{NO}$ \\
\hline $\begin{array}{l}\text { Energy injected to grid in } \\
\text { Design } 1 \quad(343.9 \text { MWh } \\
\text { power per year) }\end{array}$ & $\begin{array}{c}326,705 \mathrm{~kg} \text { (i.e. } \\
343.9 * 1000 \mathrm{kWh} * 0.95 \\
\mathrm{~kg} / \mathrm{kWh})\end{array}$ & $\begin{array}{c}2476.1 \mathrm{~kg} \text { (i.e. } \\
343.9 * 1000 \mathrm{kWh} * 7.2 \\
\mathrm{~g} / \mathrm{kWh})\end{array}$ & $\begin{array}{c}1506.3 \mathrm{~kg} \text { (i.e. } \\
343.9 * 1000 \mathrm{kWh} * 4.38 \\
\mathrm{~g} / \mathrm{kWh})\end{array}$ \\
\hline $\begin{array}{l}\text { Energy injected to grid } \\
\text { Design } 2 \text { (387.6 } \mathrm{MWh} \\
\text { power per year) }\end{array}$ & $\begin{array}{c}368,220 \mathrm{~kg} \text { (i.e. } \\
387.6 * 1000 \mathrm{kWh} * 0.95 \\
\mathrm{~kg} / \mathrm{kWh})\end{array}$ & $\begin{array}{c}2790.8 \mathrm{~kg} \text { (i.e. } \\
387.6^{*} 1000 \mathrm{kWh} * 7.2 \\
\mathrm{~g} / \mathrm{kWh})\end{array}$ & $\begin{array}{c}1697.7 \mathrm{~kg} \text { (i.e. } \\
387.6 * 1000 \mathrm{kWh} * 4.38 \\
\mathrm{~g} / \mathrm{kWh})\end{array}$ \\
\hline
\end{tabular}

518

\subsection{Economic and cost analysis}

521 As discussed earlier in Section 3.2, (refer to Table 2 \& 3) the installation cost of the PV plant is about ₹ 9,992,000

522 and the investment can be recovered in about 4 years considering some unavoidable losses.

523 The cost examination and estimation can be comprehended by utilizing a portion of the accompanying visual cues:

- Cost of panel per Watt- 40 rupees

- Estimated cost for whole plant $-40 * 248000=₹ 9,920,000$

- Electricity per year for $1 \mathrm{~kW}$ installed power-1500 units

- Electricity per day- $1500 / 365=4.2$ units/per day

- $\quad$ Money saved per year-₹ 2,604,000

- $\quad$ Electricity bill cost per unit-₹ 7 per unit $(248 * 1500 * 7=₹ 2,604,000)$

- Number of year required for return of investment-9,920,000/2,604,000 $=3.8$ years

- Actual Number of year required for return of investment due to maintenance- 4 years

- Rate of Return of investment- $-1 / 4=25 \%$

This is a very profitable solution for the electricity demand for the given industrial unit. The only disadvantage associated with the system installation is that the Indian government only allows $50 \%$ of the sanction load to be installed on one's industrial unit (to avoid unauthorized trading of energy). As a general solar industry rule of thumb, solar panels last about 25-30 years. However, this does not mean that they stop producing electricity after 25 years - it just means that energy production has declined by what manufacturers consider to be a significant amount. Performance reports from various sources have proven that the PV system can efficiently work for 2530 years. 


\section{Conclusions}

543 This study presented a novel design of a $248 \mathrm{~kW}$ PV system, which was developed in order to improve the 544 efficiency of an existing PV plant located on the rooftop of the G.D. Naidu Block at Vellore Institute of 545 Technology (Vellore, India). A cost-effective energy solution, which permits to save a huge amount of money 546 and time during the PV system installation, was obtained through a robust design of the system. To achieve the maximum energy efficiency in the novel photovoltaic system, the following aspects were considered:

- A robust design allows quantifying the full potential of the system and how to exploit it at the maximum extent.

- The PVsyst simulation software permits to determine the maximum potential of the PV plant by means of a risk analysis. Design options should be properly selected to avoid failures and maximize the efficiency of the PV system. This allows to save huge amounts of money and time.

The results of numerical simulations run in PVsyst proved that the newly developed Design 2 gives out the maximum energy to grid (about $40 \mathrm{MWh}$ more than the existing Design 1) and presents less energy losses through the energy conversion process. This resulted also in a significant reduction of $\mathrm{CO}_{2} / \mathrm{SO}_{2} / \mathrm{NO}$ emissions. The economic analysis of the two designs indicated that Design 2 is better than Design 1. However, the conversion ratio of incident sunlight/irradiation to electric energy appears to be very low. For both systems, panel efficiency was estimated to range between 12 and $18 \%$ over the year covered by simulations. Shading analysis, loss study and risk analysis allowed not decreasing too much the conversion efficiency of the designed PV system. New design solutions such as building integrated PV system (BIPV), Concentrated PV system, Dual-axis tracker system etc. can easily be tested and mastered using the design framework developed in this study. The PVsyst software may be used as a digital twin to cover the whole process from the conceptual design of a new PV system to the evaluation of its performance over a certain period of time. In this context, numerical trials may be conducted to evaluate new hardware and testing procedures. At long last, performance proportion of proposed configuration (Design 2) is 0.791 while for the current structure (Design 1) is 0.704 . Plant 2 gives $40 \mathrm{MWh}$ more vitality to lattice than Design 1 because of decreasing concealing adversity. The daily system energy generated for Design 2 is maximum, 26-29\% higher than for Design 1, between March and May, when the sun is brightest and directly above our head. The shading losses were found to be about 11-13\% lower for Design 2 as compared to Design 1, which leads to improve efficiency of energy production.

\section{References}

Abreu, J., Wingartz, N., Hardy, N., 2019. New trends in solar: A comparative study assessing the attitudes towards 
Al-Najideen, M.I., Alrwashdeh, S.S., 2017. Design of a solar photovoltaic system to cover the electricity demand for the faculty of Engineering- Mu'tah University in Jordan. Resource-Efficient Tech. 3, 440-445. http://dx.doi.org/10.1016/j.reffit.2017.04.005.

578 Allouhi, A., Saadani, R., Buker, M.S., Kousksou, T., Jamila, A., Rahmouneb, M., 2019. Energetic, economic and environmental (3E) analyses and LCOE estimation of three technologies of PV grid-connected systems under different climates. Sol. Energy 178, 25-36. https://doi.org/10.1016/j.solener.2018.11.060. Alsadi, S., Khatib, T., 2018. Photovoltaic power systems optimization research status: A review of criteria, constraints, models, techniques and software tools. Appl. Sci 8, Article No. 1761. Doi: 10.3390/app8101761. Andler, J., Mathur, N., Sutherland, J., Zhao, F., Handwerker, C., 2020. Guiding the environmental design of a novel solar absorber through life cycle assessment by identifying anticipated hot spots. J. Clean. Prod. 258, 120847. https://doi.org/10.1016/j.jclepro.2020.120847. Arefin, S.S., Das, N., 2017. Optimized hybrid wind-diesel energy system with feasibility analysis. Technol Econ Smart Grids Sustain Energy 2, 2-9. DOI 10.1007/s40866-017-0025-6.

Arefin, M.S., Raihan, M.K., Alvee, H.H., Reja, M.I., 2017. A study on feasibility of renewable hybrid power generation plant in Manpura Island. Proceedings of the International Conference on Mechanical Engineering and Renewable Energy. Chittagong, Bangladesh. ICMERE-2017. grid-connected PV/battery system using the teaching-learning-based optimization algorithm. Sol. Energy 203, 6982. https://doi.org/10.1016/j.solener.2020.04.007. Barakat, S., Ibrahim, H., Elbaset, A.A., 2020. Multi-objective optimization of grid-connected PV-wind hybrid system considering reliability, cost, and environmental aspects. Sustain. Cities Soc. 60, 102178. https://doi.org/10.1016/j.scs.2020.102178.

597 Bawazir, R.O., Cetin, N.S., 2020. Comprehensive overview of optimizing PV-DG allocation in power system and 598 solar energy resource potential assessments. Energy Rep.6, 173-208. https://doi.org/10.1016/j.egyr.2019.12.010 . 599 Campana, P.E., Landelius, T., Andersson, S., Lundstrom, L., Nordlander, E., He, T., Zhang, J., Stridh, B., Yan, 600 J., 2020. A gridded optimization model for photovoltaic applications. Sol. Energy 202, 465-484. 601 https://doi.org/10.1016/j.solener.2020.03.076.

602 Cardenas, L., Zapata, M., Franco, C.J., Dyner, I., 2017. Assessing the combined effect of the diffusion of solar 
605 Chen, W., Yang, M., Zhang, S., Andrews-Speed, P., Li, W., 2019. What accounts for the China-US difference in 606 solar PV electricity output? An LMDI analysis. J. Clean. Prod. 231, 161-170. 607 https://doi.org/10.1016/j.jclepro.2019.05.207.

608 Cho, J.-H., Chun, M.-G., Hong, W.-P., 2016. Structure optimization of stand-alone renewable power systems 609 based on multi object function. Energies 9, Article No. 649; doi:10.3390/en9080649.

610 Cristaldi, L., Faifer, M., Lazzaroni, M., Fattah Khalil, M.M.A., Catelani, M., Ciani, L., 2014. Failure modes 611 analysis and diagnostic architecture for photovoltaic plants. Proceedings of the 13th IMEKO TC10 Workshop on 612 Technical Diagnostics, Warsaw (Poland), June 2014.

613 Dondariya, C., Porwal, D., Awasthi, A., Shukla, A.K., Sudhakar, K., Murali, M.S.R., Bhimte, A., 2018.

614 Performance simulation of grid-connected rooftop solar PV system for small households: A case study of Ujjain,

615 India. Energy Reports 4, 546-553. https://doi.org/10.1016/j.egyr.2018.08.002.

616 Elbar, A.R.A., Yousef, M.S., Hassan, H., 2019. Energy, exergy, exergoeconomic and enviroeconomic (4E)

617 evaluation of a new integration of solar still with photovoltaic panel. J. Clean. Prod. 233, 665-680.

618 https://doi.org/10.1016/j.jclepro.2019.06.111.

619 Farias-Rocha, A.P., Hassan, K.M.K., Malimata, J.R.R., Sánchez-Cubedo, G.A., Rojas-Solórzano, L.R., 2019.

620 Solar photovoltaic policy review and economic analysis for on-grid residential installations in the Philippines. J.

621 Clean. Prod. 223, 45-56.https://doi.org/10.1016/j.jclepro.2019.03.085.

622 Gallardo-Saavedra, S., Hernandez-Callejo, L., Duque-Paerez, O., 2019. Quantitative failure rates and modes analysis in photovoltaic plants. Energy 183, 825-836. https://doi.org/10.1016/j.energy.2019.06.185.

624 Goel, M., 2016. Solar rooftop in India: Policies, challenges and outlook. Green Energy \& Environment 22, 129137. doi: $10.1016 /$ j.gee.2016.08.003.

626 Good, C.S., Lobaccaro, G., Harklau, S., 2014. Optimization of solar energy potential for buildings in urban areas627 a Norwegian case study. Energy Procedia 58, 166-171. doi: 10.1016/j.egypro.2014.10.424.

628 Ghasemi-Mobtaker, H., Mostashari-Rad, F., Saber, Z., Chau, W.-W., Nabavi-Pelesaraei, A 2020. Application of photovoltaic system to modify energy use, environmental damages and cumulative exergy demand of two 630 irrigation systems-A case study: Barley production of Iran. Renewable Energy 160, 1316-1334. https://doi.org/10.1016/j.renene.2020.07.047.

632 Hasan, M., Momin, O.B., 2015. Performance analysis and feasibility study of solar-wind-diesel hybrid power system in rural areas of Bangladesh. I. J. Engg. Res. And General Science $3,5$. 
635 Heusinger, J., Broadbent, A.M., Sailora, D.J., Georgescu, M., 2020. Introduction, evaluation and application of 636 an energy balance model for photovoltaic modules. Sol. Energy 195, 382-395. 637 https://doi.org/10.1016/j.solener.2019.11.041.

638 Hocine, L., Samira, K.M., 2019. Optimal PV panel's end-life assessment based on the supervision of their own 639 aging evolution and waste management forecasting. Sol. Energy 191, 227-234. $640 \quad$ https://doi.org/10.1016/j.solener.2019.08.058.

641 Hossain, M., Mekhilef, S., Danesh, M., Olatomiwa, L., Shamshirband, S., 2017. Application of extreme learning 642 machine for short term output power forecasting of three grid-connected PV systems. J. Clean. Prod. 167, 395643 405. http://dx.doi.org/10.1016/j.jclepro.2017.08.081.

644 Hosseini-Fashami, F., Motevali, A., Nabavi-Pelesaraei, A., Hashemi, S.J., Chau, K.-W., 2019. Energy-Life cycle 645 assessment on applying solar technologies for greenhouse strawberry production. Renewable and Sustainable 646 Energy Reviews 116, 109411. https://doi.org/10.1016/j.rser.2019.109411

647 Irwan, Y.M., Amelia, A.R., Irwanto, M., Fareq, M., Leow, W.Z., Gomesh, N., Safwati, I., 2015. Stand-Alone 648 Photovoltaic (SAPV) System Assessment using PVSYSTEM Software. Energy Procedia 79, 596-603. doi: $649 \quad$ 10.1016/j.egypro.2015.11.539.

650 Jain, S., Jain, N.K., Vaughn, W.J., 2018. Challenges in meeting all of India's electricity from solar: An energetic 651 approach. Renewable and Sustainable Energy Reviews 82, 1006-1013. 652 http://dx.doi.org/10.1016/j.rser.2017.09.099.

653 Jiang, P., Wang, Y., Peng, Z., 2018. The application potential of solar energy sources in Shanghai’s existing 654 workers’ village. Energy Procedia 152, 1085-1090. doi: 10.1016/j.egypro.2018.09.127.

655 Kabeel, A.E., Abdelgaied, M., 2019. Performance enhancement of a photovoltaic panel with reflectors and cooling 656 coupled to a solar still with air injection. J. Clean. Prod. 224, 40-49. https://doi.org/10.1016/j.jclepro.2019.03.199.

657 Kar, S.K., Sharma, A., Roy, B., 2016. Solar energy market developments in India. Renew.Sust.Energ. Rev. 62, 658 121-133. http://dx.doi.org/10.1016/j.rser.2016.04.043.

659 Katekar, V.P., Deshmukh, S.S., 2020. A review on research trends in solar still designs for domestic and industrial 660 applications. J. Clean Prod. 257. Article No. 120544. https://doi.org/10.1016/j.jclepro.2020.120544.

661 Khare, A., Rangnekar, S., 2013. A review of particle swarm optimization and its applications in solar photovoltaic 662 systems. Appl. Soft Comp. 12(5), 2997-3006. 
665 Kim, N., Hwang, K., Kim, D., Lee, J.H., Jeong, D.H., 2016. Analysis and reproduction of snail trails on silver 666 grid lines in crystalline silicon photovoltaic modules. Sol. Energy 124, 153-162.

667 Krauter, S., 2018. Simple and effective methods to match photovoltaic power generation to the grid load profile 668 for a PV based energy system. Sol. Energy 159, 768-776. https://doi.org/10.1016/j.solener.2017.11.039.

669 Kumar, M., Chandel, S.S., Kumar, A., 2020. Performance analysis of a 10 MWp utility scale grid-connected 670 canal-top photovoltaic power plant under Indian climatic conditions. Energy 204, Article No. 117903. 671 https://doi.org/10.1016/j.energy.2020.117903

672 Li, Y., Liu, C., 2018. Revenue assessment and visualisation of photovoltaic projects on building envelopes. J. 673 Clean. Prod. 182, 177-186. https://doi.org/10.1016/j.jclepro.2018.01.128.

674 Lillo-Bravo, I., Pablo González-Martínez, P., Larrañeta, M., Guasumba-Codena, J, 2018. Impact of energy losses 675 due to failures on photovoltaic plant energy balance. Energies 11, Article No. 363; doi:10.3390/en11020363.

676 Mazzeo, D., Baglivo, C., Matera, N., Congedo, P.M., Oliveti, G., 2020. A novel energy-economic-environmental 677 multi-criteria decision-making in the optimization of a hybrid renewable system. Sustain. Cities Soc. 52, 101780. $678 \quad$ https://doi.org/10.1016/j.scs.2019.101780.

679 Meyer, S., Richter, S., Timmel, S., Gläser, M., Werner, M., Swatek, S., Hagendorf, C., 2013. Snail trails: root 680 cause analysis and test procedures. Energy Procedia 38, 498-505. doi: 10.1016/j.egypro.2013.07.309.

681 Mishra, M.K., Lal, V.N., 2020. An improved methodology for reactive power management in grid integrated solar 682 PV system with maximum power point condition.Sol. Energy 199, 230-245. 683 https://doi.org/10.1016/j.solener.2020.02.001.

684 Mohamed, A.S.A., El-Sayed, A., Metwally, H., Selem, S.I., 2020. Grid integration of a PV system supporting an 685 EV charging station using Salp Swarm Optimization. Sol. Energy 205, 170-182. 686 https://doi.org/10.1016/j.solener.2020.05.013.

687 Mohammadi, S., Vries, B.D., Schaefer, W., 2014. Modelling the allocation and economic evaluation of PV panels 688 and wind turbines in urban areas. Procedia Env. Sci. doi: 10.1016/j.proenv.2014.11.032.

689 Mohsenipour, M., Ebadollahi, M., Rostamzadeh, H., Amidpour, M., 2020. Design and evaluation of a solar- based 690 trigeneration system for a nearly zero energy greenhouse in arid region. J. Clean. Prod. 254, 119990. 691 https://doi.org/10.1016/j.jclepro.2020.119990.

692 Mondal, R., Panja, S., 2016. Design and feasibility study of a small scale grid connected solar PV power plant. 
694 Nehme, B., Msirdi, N.K., Nammane, A., Akiki, T., 2017. Analysis and characterization of faults in PV panels.

695 Energy Procedia 111, 1020-1029. Doi:10.1016/j.egypro.2017.03.265.

696 Overholm, H., 2015. Spreading the rooftop revolution: What policies enable solar-as-a-service? Energy Policy 697 84, 69-79. http://dx.doi.org/10.1016/j.enpol.2015.04.021.

698 Paulo, A.F.D., Porto, G.S., 2018. Evolution of collaborative networks of solar energy applied technologies. J.

699 Clean. Prod. 204, 310-320. https://doi.org/10.1016/j.jclepro.2018.08.344.

700 Perea-Moreno, A.J., García-Cruz, A., Novas, N., Manzano-Agugliaro, F., 2017. Rooftop analysis for solar flat 701 plate collector assessment to achieving sustainability energy. J. Clean. Prod. 148, 545-554. 702 http://dx.doi.org/10.1016/j.jclepro.2017.02.019.

703 PVsyst: Software for Photovoltaic System. Version 6.70. PVsyst SA, Satigny, Switzerland. 704 http://www.PVsyst.com/en.

705 Rehman, H., Hirvonen, J., Sirén, K., 2018. Influence of technical failures on the performance of an optimized 706 community-size solar heating system in Nordic conditions. J. Clean. Prod. 175, 624707 640.https://doi.org/10.1016/j.jclepro.2017.12.088.

708 Ridha, H.M., Gomes, C., Hizam, H. Ahmadipour, M., 2020. Optimal design of standalone photovoltaic system 709 based on multi-objective particle swarm optimization: a case study of Malaysia. Processes, 8(1), Article No. 41; 710 https://doi.org/10.3390/pr8010041.

711 Robles-Campos, H.R., Azuaje-Berbecía, B.J., Schellera, C.J., Angulob, A., Mancilla-Davida, F., 2019. Detailed 712 modelling of large scale photovoltaic power plants under partial shading conditions. Sol. Energy 194, 485-498.

713 https://doi.org/10.1016/j.solener.2019.10.043.

714 Singh, S., Singh, M., Kaushik, S.C., 2016. A review on optimization techniques for sizing of solar-wind hybrid 715 energy systems. Int. J. Green Energy 13(15), 1564-1578; DOI: 10.1080/15435075.2016.1207079.

716 Shezan, S.A., Das, N., Mahmudul, H., 2017. Techno-economic analysis of a smart-grid hybrid renewable energy

717 system for Brisbane of Australia. Energy Procedia 110, 340-345. Doi:10.1016/j.egypro.2017.03.150.

718 Shukla, A.K., Sudhakar, K., Baredar, P., 2016. Simulation and performance analysis of $110 \mathrm{kWp}$ grid-connected 719 photovoltaic system for residential building in India: A comparative analysis of various PV technology. Energy 720 Reports 2, 82-88.http://dx.doi.org/10.1016/j.egyr.2016.04.001.

721 Shukla, A.K., Sudhakar, K., Baredar, P., Mamat, R., 2018. Solar PV and BIPV system: Barrier, challenges and policy recommendation in India. Renewable and Sustainable Energy Reviews 82, 3314- 
Sivaneasan, B., Yu, C.Y., Goh, K.P., 2017. Solar forecasting using ANN with Fuzzy logic pre-processing. Energy Procedia 143, 727-732. doi: 10.1016/j.egypro.2017.12.753.

Thakur, J., Chakraborty, B., 2018. Impact of increased solar penetration on bill savings of net metered residential consumers in India. Energy 162, 776-786. https://doi.org/10.1016/j.energy.2018.08.025.

Thakur, J., Rauner, S., Darghouth, N.R., Chakraborty, B., 2018. Exploring the impact of increased solar deployment levels on residential electricity bills in India. Renewable Energy 120, 512-523.

730 https://doi.org/10.1016/j.renene.2017.12.101.

731 Thotakura, S., Kondamudi, S.C., Xavier, J.F., Quanjin, M., Reddy, G.R., Gangwar, P., Davuluri, S.L., 2020.

732 Operational performance of megawatt-scale grid integrated rooftop solar PV system in tropical wet and dry 733 climates of India. Case Studies in Thermal Engineering 18, 100602.https://doi.org/10.1016/j.csite.2020.100602.

734 Wang, L., Singh, C., 2007. PSO-Based Multi-Criteria optimum design of a grid-connected hybrid power system 735 with multiple renewable sources of energy. Proceedings of the 2007 IEEE Swarm Intelligence Symposium (SIS 2007). IEEE Explore.

737 Wang, Y., Liu, F., Zhang, X., Sun, Z., 2012. Game approaches for hybrid power system planning. IEEE Transactions on Sustainable Energy 3, 506-517. IEEE Explore.

739 Wang, J., Yang, F., 2013. Optimal capacity allocation of standalone wind/solar/battery hybrid power system based 740 on improved particle swarm optimisation algorithm. IET Renewable Power Generation 7, 443-448. Doi: $741 \quad$ 10.1049/iet-rpg.2012.0329.

742 Yadav, S.K., Bajpai, U., 2018. Performance evaluation of a rooftop solar photovoltaic power plant in Northern 743 India. Energy for Sustainable Development43, 130-138. https://doi.org/10.1016/j.esd.2018.01.006.

744 Yu, Z., Gou, Z., Qian, F., Fu, J., Tao, Y., 2019. Towards an optimized zero energy solar house: A critical analysis 745 of passive and active design strategies used in Solar Decathlon Europe in Madrid. J. Clean. Prod. 236, $746 \quad$ 117646.https://doi.org/10.1016/j.jclepro.2019.117646.

747 Zheng, X., Dai, T., Tang, M., 2020. An experimental study of vertical greenery systems for window shading for 748 energy saving in summer. J. Clean. Prod. 259, 120708. https://doi.org/10.1016/j.jclepro.2020.120708.

749 Zinaddinov, M., Mil'shtein, S., Kazmer. D., 2019. Design of light-weight solar panels. Proceedings of the PVSC750 46, Chicago (USA). 